University of Rhode Island

DigitalCommons@URI

Open Access Master's Theses

1989

\title{
A Study on Causal Thinking Young Children's Ability to Differentiate Fantasy from Reality
}

\author{
Ellen Lee Kenner \\ University of Rhode Island
}

Follow this and additional works at: https://digitalcommons.uri.edu/theses

\section{Recommended Citation}

Kenner, Ellen Lee, "A Study on Causal Thinking Young Children's Ability to Differentiate Fantasy from Reality" (1989). Open Access Master's Theses. Paper 1686.

https://digitalcommons.uri.edu/theses/1686

This Thesis is brought to you for free and open access by DigitalCommons@URI. It has been accepted for inclusion in Open Access Master's Theses by an authorized administrator of DigitalCommons@URI. For more information, please contact digitalcommons-group@uri.edu. 


\title{
A STUDY ON CAUSAL THINKING
}

YOUNG CHILDREN'S ABILITY TO DIFFERENTIATE

FANTASY FROM REALITY

BY

ELLEN LEE KENNER

A THESIS SUBMITTED IN PARTIAL FULFILLMENT OF THE REQUIREMENTS FOR THE DEGREE OF MASTER OF ARTS

IN

PSYCHOLOGY

\author{
UNIVERSITY OF RHODE ISLAND \\ 1989
}




\section{ABSTRACT}

According to Piaget, children in the "preoperational stage" of development have difficulty separating fantasy from reality, the mental realm from the physical realm. This stage theory of cognitive development is called into question by the current study. In this study, 48 four-year olds performed a judgment task consisting of causality questions after having listened to either a fantasy or a reality based story. Results from the Tukey test across story types and the control group (no story) support the hypothesis that children can differentiate physical entities from thoughts about physical entities, (i.e., Tukey summary statistic, $\mathrm{dT}=58.07, \mathrm{p}(.05)$ and physical entities from thoughts about fantastical entities, (i.e., Tukey summary statistic, $\mathrm{dT}=63.80, \mathrm{p}(.05)$. It was also found that children can differentiate fantasy from reality. Findings show that the environmental influence (fantasy or reality story) had no influence on the nature of the children's responses in the subsequent judgment task. Results from two experimenters concurred with the above findings, however their results differed significantly from each other. Verbal responses given by the children further support the data that children can differentiate the mental realm from the physical realm. 


\section{ACKNOWLEDGMENTS}

My very special thanks goes to my husband, Harris, whose gentle kindness, support and humor helped make this an enjoyable project.

Dr. Allan Berman's encouragement and enthusiasm about this project was very important to me as was Dr. Lisa Harlow's strong suggestions that I delimit the project along with her help on statistics.

I give special thanks to my assistant, Carol MacAndrew whose presence added a warmth and a playful maturity to the actual testing of the children. And my thanks goes to Mrs. Plouffe of the Kent County YMCA Y's Owl Nursery School for her generous welcome and assistance in running half of the study at her school.

I am appreciative of the other teachers who were involved in this study and my thanks goes to them and to the parents and children who participated - and to the friendly historian, Dr. Joel Cohen. 


\section{PREFACE}

This thesis investigates the effect of the environment (naturalistic or non-naturalistic influences) on a young child's ability to distinguish between real physical phenomena and mental phenomena le.g., an actual tangible kitty versus a thought about a kitty or a thought about a fantastical impossible kitty, such as one which can fly). It is based on some research done by Wellman and Estes (1986) and Koutsourais (1984).

Piaget (1952, 1962, 1969, 1971, 1972; in Bringuier, 1980) has hypothesized that children between the ages of two to seven are in a "preoperational" developmental stage. Briefly, Piaget saw this stage as one in which the child's mental capabilities are not well enough developed to allow them to distinguish real physical events from mental events (See Appendix A for an outline of the Preoperational stage). Piaget states the following:

During the early stages the world and the self are one; neither term is distinguished from the other. But when they become distinct, these two terms begin by remaining very close to each other: the world is still conscious and full of intentions, the self is still material...only slightly interiorized (Piaget, 1951, 244).

Piaget theorizes that children's causal thinking is qualitatively, not just quantatively different from adult 
thinking. Many investigators agree with Piaget. Most prominently, Sohan and Celia Modgil (1974; vols 1-8, 1976; 1982 ) have extended and extensively analyzed and reviewed much of the literature and studies concerning Piaget's work. Among their accomplishments, they have published nine volumes on Piagetian Research. Barbel Inhelder worked with Piaget on the book, The Growth of Logical Thinking (1958) and also published a book with Hermaine Sinclair and Magali Bovet $(1974)$.

However, recent investigators, e.g., Wellman and Estes (1986), Berzonsky (1971), Prentice, Manosevitz and Hubbs (1978), have found that by using different methods, they were able to demonstrate that children have the ability to distinguish between mental and real physical events during this Piagetian "preoperational" period. If children in this preoperational stage are indeed capable of distinguishing the mental from the physical realm, what other factors might account for the fact that some children do not readily demonstrate this ability? The current study looked at environmental influences that were thought to strongly contribute to a child's ability in this area, namely non-naturalistic stories. The results did not confirm this thesis; children performing a judgment task after hearing a non-naturalistic story did not get results that differed from children hearing a naturalistic story.

However, this study did confirm Wellman and Estes 
(1986) evidence that four year olds can distinguish between the physical and mental realms and between the mental possible realm (e.g., a thought about a kitty) and the mental impossible realm (e.g., a thought about a kitty that flies).

Two points of clarification need to be stressed at the outset. One concerns the term "realism". As used by Piaget, it refers to the attribution of physical status (e.g., one can touch with one' hands, or see with one's eyes) to mental contents such as the content of a thought or dream. Hence, a child might honestly believe that a dreamed cat exists and can be physically interacted with, i.e., the dreamed cat is physical, or "real" - hence the term "realism". This definition runs counter to a common sense understanding of the term realism, i.e., something natural, real and physical, which is NOT Piaget's meaning.

The second clarification involves the classification of the mental and physical realm. This distinction has been referred to by numerous terms which the following chart indicates:

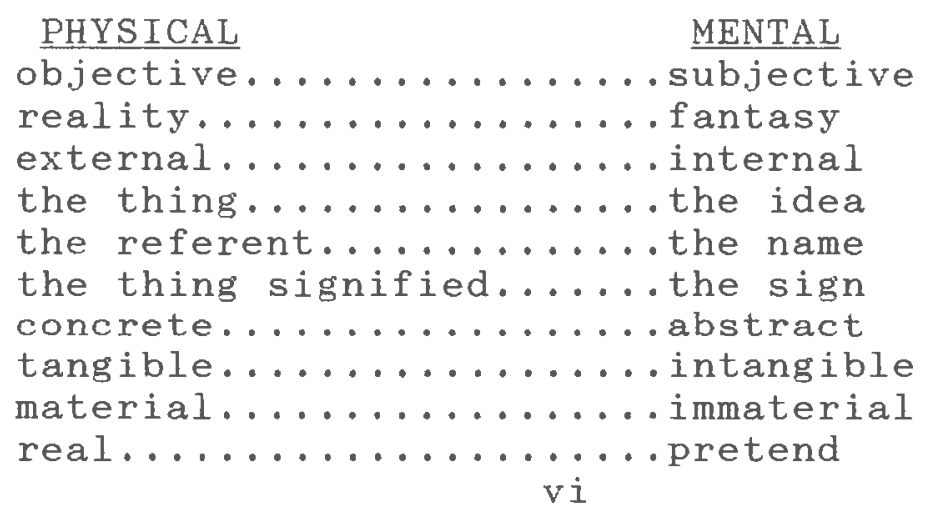


For the sake of clarity, I will emphasize the term "physical" rather than "real" when referring to the physical realm in distinction to the mental realm because the mental realm can also be considered real, i.e., thoughts ARE real in a certain sense. However, in referring to one aspect of the mental realm, I will interchangeably use the terms "mental-impossible" and "fantasy" to designate thoughts about things that are possible to think of (epistemologically possible) yet impossible in a physical sense (metaphysically impossible), such as a flying kitty. 
Abstract..........................

Acknowledgments......................ii

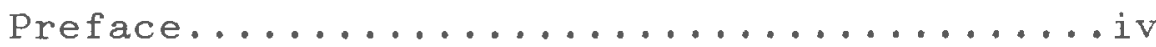

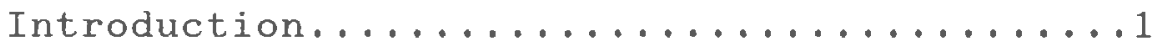

Piaget's Clinical Approach............1

Methodology used by other

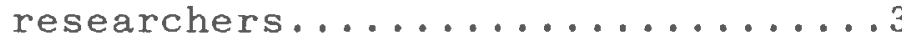

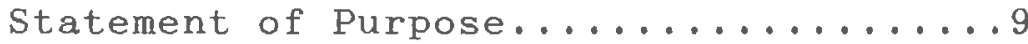

Methods

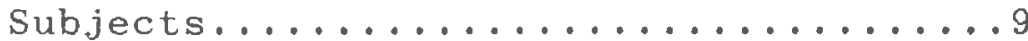

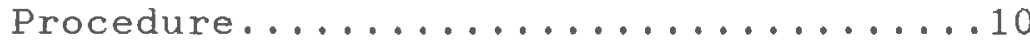

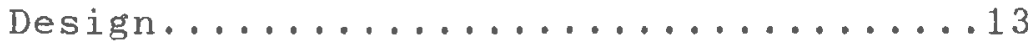

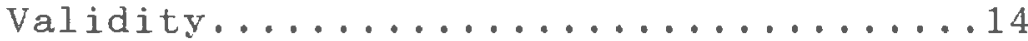

Experiment 1

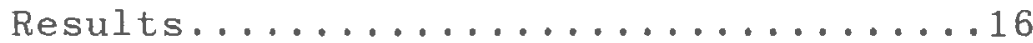

Experiment II

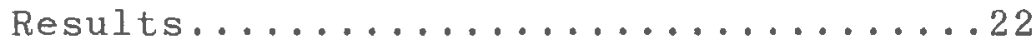

Categories of Explanation..........25

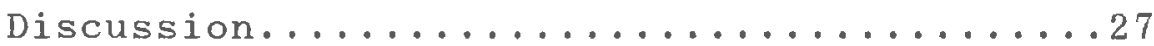

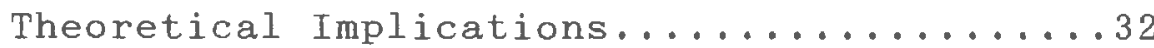

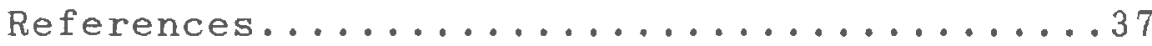

Appendix

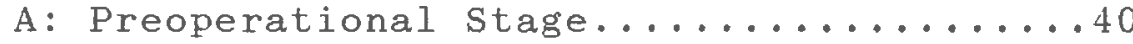

B: Types of Causal Reasoning...........42

C: Informed Consent................443

D: Demographic Questionnaire...........45

E: Demographic Graphs................44

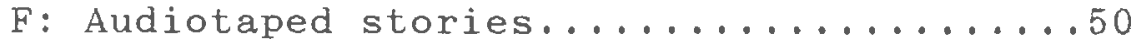

G: Categories of Explanation............52

H: Children's Verbal Responses..........53

I: Favorite Movies, Books, TV...........63

Bibliography....................68 


\section{LIST OF TABLES}

Table 1: Post-test Control \& Contrast Group Design...13

Table 2: Means of the Two-way Interaction..........20

Table 3: Analysis of Simple Effects (Judgment).....20

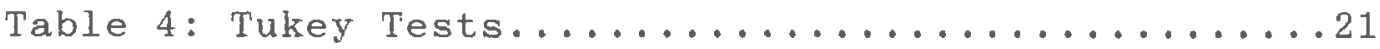

Table 5: Analysis of Simple Effects (Experimenter)...22

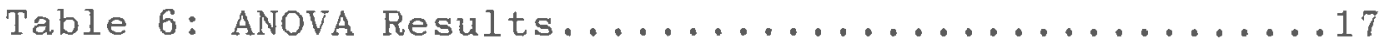

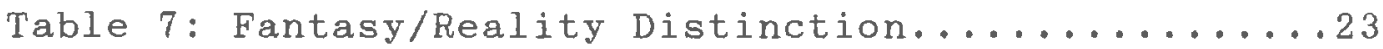

Table 8: Categories of Explanation..............25 


\section{LIST OF FIGURES}

Figure 1: Means as a Function(Judgment $\mathrm{x}$ Experimenter....18

Figure 2: Means as a Function(Judgment $x$ Experimenter)...19 (The above two are plotted on different axes)

Figure 3: Fantasy/Reality Distinction...............24

Figure 4 : Neighborhood setting.................. 47

Figure 5: Parents Education......................

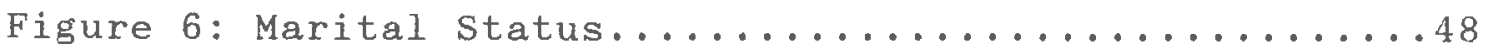

Figure 7 : Sibling Information..................

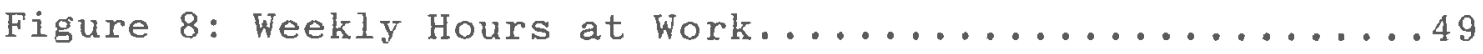

Figure $9:$ Family Income......................49 


\section{INTRODUCTION}

Various methods have been used to determine how and when a child learns to distinguish mental phenomena from physical phenomena. Most notably, the prodigious studies by Jean Piaget have sought to answer these questions. In studying and categorizing children's causal explanations, Piaget developed a stage theory of cognitive development.

\section{Piaget's Clinical Approach}

Piaget theorized that children roughly between the ages of two to seven years pass through a stage of causal reasoning dominated by the following types of thinking (Piaget, 1952, 1962, 1969):

1. Motivational causality

5. Magical causality

2. Phenomenistic causality

6. Animistic causality

3. Finalistic causality

4. Moralistic causality

7. Artificialistic causality (see Appendix B for definitions)

In trying to grasp how children distinguish mental from physical activities, Piaget's questions were on the order of "What is thinking?" "What do you think with?" "What is thought?" "Where is the dream made?" "Where do dreams take place?" "Can dreams be red or heavy?" Wellman and Estes (1986) criticize such questions as being misleading. It is misleading to ask what dreams are made of for it implies that dreams are material in nature, and the child may not yet have the abstract concepts to describe the mental nature 
of dreams, although they ostensibly can note similarities and differences between dreams and tangible existents. Also, the CONTENT of a dream can be heavy or red and the child might think the questioner is commenting on the content of the dream and not the abstraction "dream" itself. Wellman and Estes comment that children often speak in a non-literal manner, using metaphors or analogies. In this way, children might be answering the questions about mental phenomena "as if" they were real physical phenomena. The following is an example of Piaget's questioning from his book The Child's Conception of the World (1929):

Kenn ( 7 1/2): What do you think with? - Inside my head. - Is the head empty or full? - Full. If someone opened your head, would they see when you were thinking? - No, because they couldn't see. - If they could look inside your head without your dying, would they see your thought? (Piaget, 1929, p.41)

From this type of clinical methodology, Piaget draws the conclusion, "The child knows nothing of the nature of thought, even at the stage when he is being influenced by adult talk concerning 'mind,' 'brain,' 'intelligence." (Piaget, 1929, p. 37).

In contrast to Piaget's ideas on the young child's ability to distinguish between fantasy and reality, an alternative interpretation is offered in the general discussion at the end of this thesis. 


\section{Methodology used by other researchers}

Although Piaget's Stage Theory of intellectual development has had much support, it has also received much criticism. Looking at the empirical literature, Wellman and Estes (1986), as mentioned, criticized Piaget's studies on the grounds of asking misleading and open-ended questions in his experiments on causality. Using real/not-real sorting tasks and judgment tasks with children ages 3-5, Wellman and Estes found that, in contrast to Piaget's conclusions, children as young as $31 / 2$ were almost consistently able to explicitly distinguish reality from fantasy. Not only that, these children were able to distinguish between mental entities that are possible (e.g., a thought about a kitty) from mental entities that are impossible (e.g., a thought about a kitty that flies), a more abstract distinction. Results of the current study support this early ability of children to make physical/ mental possible/ metal impossible distinctions.

Berzonsky (1971) also questioned Piaget's Stage Theory. He looked at how children "phenomenistically" explain cause and effect. Using a 22 question interview, a teeter-totter task and a water level apparatus with six and seven year olds, Berzonsky found that a decisive factor in children's causal thinking is their FAMILIARITY with the objects or events in question. Again, Piaget's emphasis on maturing intellectual structures and his de-emphasis on the role of 
experience in children's causal reasoning is unsupported by the results of this study.

Morrison and Gardner (1978) used card sorting tasks and verbatim protocols to specify the characteristics children use to distinguish fantasy from reality. Their results raise questions about the appropriateness of Piaget's methodology. Their subjects were kindergarten, second, fourth and sixth graders. Their results indicate that fantasy characters were distinguished from real characters in terms of their POWER and MAGIC. They noted that although younger children have some difficulty expressing their knowledge VERBALLY, they do demonstrate their understanding of real versus pretend in card sorting tasks. This brings into question Piaget's methodology: did his methods accurately tap children's abilities?

Prentice, Manosevitz and Hubbs (1978) found a correlation between a child's belief or non-belief in mythical figures and parental encouragement or discouragement of such beliefs. They found that parents who encouraged children to believe had children who believed, whereas the six parents in their study who discouraged belief in Santa Claus had children who all disbelieved. This study lends support to the idea that parents play an important role in their children's ability to distinguish fantasy from reality.

Lesser and Paisner (1985) take an entirely different 
angle on investigating Piaget's Stage Theory of causal reasoning. Using a causality interview and Randall and DesRosier's (1980) Measurement of Supernatural Belief scale, they found that adults in a New Age (religious sect) community showed thinking characteristic of Piaget's preoperational stage of mental development (ages 2-7). For example, Lesser and Paisner quote a woman as stating the following:

This is very subtle, and sounds kind of weird, probably, but I feel like what happens collectively among people affects weather. I mean I believe that Indians doing dances, rain dances, can create rain. ( $p$. $69)$

The fact that many adults in this study demonstrate "preoperational" causal thinking, seriously draws into question Piaget's notion that concepts of causality develop in tandem with developing mental logical structures. Dworetzsky (1984), in a chapter on Piaget, comments that "The fact that we develop cognitively doesn't necessarily mean that we develop the ability to distinguish truth from fiction." What could account for this seeming contradictionthat many adults could be in the preoperational stage?

Koutsourais (1984) looked at environmental influences on children's causal thinking. Specifically, she looked at the influence of story telling on children's causal explanations. Using a story about evaporation told to 4 and 5 year olds, she found that magical thinking still occurred 
after the children had been given a more naturalistic explanation for the event (evaporation) in the story. Also, the naturalistic explanation offered by the experimenter did not generalize to another story for which the children gave explanations. Koutsourais feels that the choice of something as abstract as evaporation, which is not part of a child's daily experience, could have masked their actual abilities. She also comments that her study did not adequately tap whether the children actually believed their non-naturalistic responses or whether they were engaging in make believe. She emphasizes the importance of asking the children whether they believe their own responses or are just pretending.

Piaget's Stage Theory of causal thinking minimizes but does not exclude the role of the environment in effecting children's causal thinking. It emphasizes that younger children don't simply know less than older children, they actualiy think differently due to the QUALITATIVELY differing underlying cognitive brain structures. older children have more advanced underlying biological cognitive structures which have also had more time to flexibly adapt to their environment.

This notion of developing age specific yet flexible "logical structures" which account for the type of reasoning a child engages in is untenable given recent empirical studies using more concrete measures. An 
alternative theory on the development of causal thinking is thought to better account for Piaget's results plus the observations in the above studies. In brief, the main discrepancies between Piaget's studies and the above studies are:

1. That young children whom Piaget would categorize as unable to explicitly differentiate mental from physical Do demonstrate their ability to do so when given less abstract tasks.

2. Adults, who should have passed through the "preoperational stage" of causal thinking onto the formal operational stage have been shown to routinely and characteristically exhibit all sorts of non-naturalistic, non-causal thinking, e.g., astrologers, palm readers, and members of the above mentioned New Age community.

Piaget's observations and descriptions about children's abilities are not in question in this study. His 50 years of studying children has stimulated much interest in the field of cognitive development. What is of concern regarding Piaget is:

a) Did his METHODS accurately tap children's abilities? - with a focus specifically on age 4 (preoperational stage)

b) Does his stage THEORY adequately account for our current empirical data, specifically data indicating that children as young perhaps as $31 / 2$ can accurately 
differentiate between the mental and physical realm? (What about parental and other environmental encouragement of fantasy?)

c) What role does environmental encouragement of non-naturalistic thinking play in the cognitive development of young children?

This area of research has widespread implications. The ideas we have about the developing child's mind influence our childrearing practices, our educational perspectives and ultimately the type of culture, politics and aesthetics that predominate. For example, different schools emphasize encouragement of naturalistic thinking (e.g., Montessori schools) whereas other schools explicitly denounce such an approach and actively encourage non-naturalistic thinking (e.g., Waldorf method). 


\section{Statement of Purpose of the Current Study}

The purpose of the current study is to examine the effect of the environment on children's causal thinking and to validate that "preoperational" children can differentiate mental phenomena from physical phenomena and that they can distinguish fantasy from reality when these distinctions are assessed very concretely.

The main hypotheses are the following:

1) That the environment can influence causal thinking in young children. Specifically, environmental encouragement of non-causal, non-naturalistic thinking will hamper a 4 year old child's ability to distinguish fantasy from reality.

2) That young children are capable of differentiating fantasy from reality; the physical from the mental possible the latter from the mental impossible.

\section{METHODS}

\section{Subjects}

Fourty-eight four year old children were selected from five nursery schools (Frenchtown Learning Center, Y's Owl, Doric Day, Johnston Childcare Center and Kindercare) and one YMCA day camp, Camp Tenderfoot in Rhode Island. Selection was dependent on parental approval and child assent (see Appendix $C$ for Parental Letter and Informed Consent). The 
24 boys and 24 girls all came from a predominately middle-class town population. Demographic questionnaires were sent home for the parents to fill out and return and 41 of the 48 questionnaires were returned. However, complete data on measures pertinent to the analyses was available on all 48 subjects. Demographic questionnaires are in Appendix $D$ and demographic information is in Appendix E.

\section{Procedure}

After receiving permission from the camp, school or day care, parental permission slips were sent home. Following parental consent, the experimenter invited the child to be in the study. This study was limited to those children who voluntarily verbalized and nonverbally indicated interest in the tasks.

Children were randomly assigned to one of three groups (control, reality-based story and fantasy-based story) in a rotating fashion. In addition each child received the six stimuli (cards: two physical, two mental possible, two mental impossible) in a randomly counterbalanced manner (using a Latin square arrangement).

Each child was individually tested in the least distractable place available. For the two treatment conditions, the children listened to a short story (approximately two minutes in length). For the control condition, no story was told. The experimenter sat facing 
the child but avoiding eye contact while the child listened to the taped story to avoid inadvertently influencing the child. All three groups were then shown colorful cards with a child on each card.

The experimenter introduced the card with a comment that the child is either THINKING ABOUT or HAS an object. The comments fall into one of three categories as listed below.

PHYSICAL

1. Susie likes cookies. Right now she HAS a cookie.

2. Joe likes puppies. Right now he HAS a puppy with him.

MENTAL - metaphysically POSSIBLE

3. Jeff is THINKING of a brownie.

4. Sara is THINKING of a bird.

MENTAL - metaphysically IMPOSSIBLE

5. Darlene is THINKING of an APPLE THAT DANCES.

6. Alex is THINKING of an ANT RIDING A BICYCLE.

After presenting each card, the children were asked six questions; the first four questions were analyzed for Experiment 1 and the last two questions were analyzed for Experiment 2. The questions are based on the three criteria differentiating the physical and mental realm as defined by Wellman and Estes (1986). The criteria are as follows:

1 ) BEHAVIORAL-SENSORY CONTACT: Real entities can be touched and they occupy an exact space. They cannot be wished away. Mental entities cannot be physically touched; they can be wished away.

2) PUBLIC EXISTENCE: Other people can also touch real entities. They cannot touch a dreamed or imagined entity. 
3) CONSISTENT EXISTENCE: Dreamed or imagined entities can disappear over time; real entities will consistently endure over time. (My real table will look the same tomorrow, a dreamed table is mentally malleable and can poof(!) out of existence.)

The actual judgment task questions the children are asked (i.e., the dependent variable) are the following:

Behavioral-sensory contact:

1. Can SEE the with her eyes?

2. Can TOLCH the with her hands?

Public Existence:

3. Can 's friend SEE the with his eyes? Consistent Existence:

4. Can (act on, e.g., "pet") her TOMORROW?

Children responded YES/NO/I DON'T KNOW, and presentation order of the stimulus cards was counterbalanced across subjects.

A further way that the mental and real differ is that mental entities can be about things that could possibly happen in reality (e.g., a flower that is red) or mental entities can be about things that are totally fantastical, imaginary and could never exist in reality (e.g., a flower that talks). The last two questions on each card investigated this ability.

5) Have you ever really seen

6) Can you close your eyes and think about

The children were asked to explain random answers. This qualitative data was analyzed separately according to the criteria used by Wellman and Estes (1986, Appendix G). This information was used to clarify the findings (actual responses are in Appendix $H$ ). 
Each child was asked a total of 36 questions, 10 cards with 6 questions on eachl, where they gave yes/no/I don't know responses (idk). The actual dependent variable was the number of yes responses over the total number of possible responses in each category.

[Dependent variable $=$ yes $/($ yes + no $+i d k)=$ percent yes] Design

A post-test only, control and contrast group, mixed factorial design was used. There were three factors involved; two between groups factors (1) the type of pretest environmental influence (no story, reality-based story, fantasy-based story) and (2) the experimenter (the author and an assistant) and one within subjects factor (the item type: physical, mental possible, mental impossible). The design is outlined below in Table 1.

Table 1

Post-test only Control and Contrast Group Design

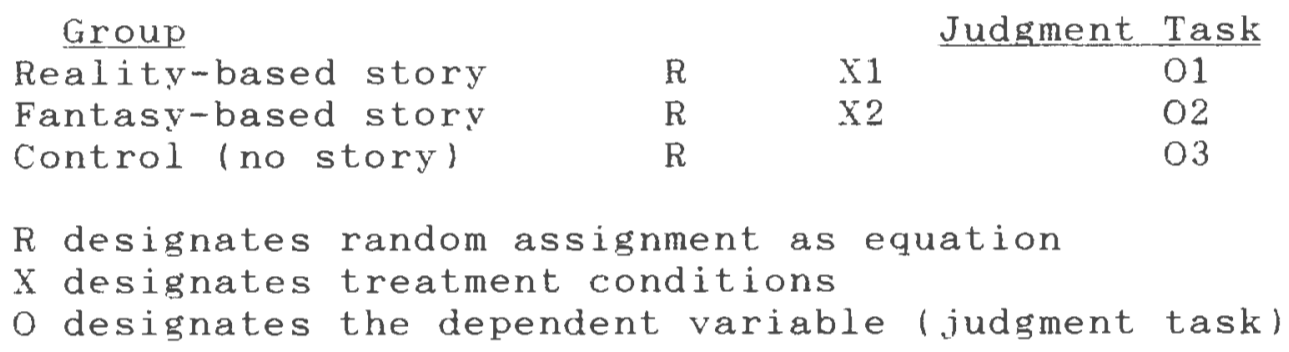

The design $(3 \times 2 \times 3)$ is considered a mixed factorial design, noted by keppel (1982) as an $A x$ B $x$ (C $x$ S) design where $A$ and $B$ represent the independent between 
groups factors (story type and experimenter), C represents the repeated measure factor (the judgment task) and $s$ represents the subject factor. ANOVA analysis using BMDP following suggestions by Collyer and Enns (1987) was conducted as the main focus of the study. Additional analyses were done on questions 5 and 6 of the judgment task as an extra validation that 4 year olds can distinguish the mental possible from the mental impossible categories.

\section{Validity}

Random assignment and ensuring an adequate and equal number of subjects per cell (6 per cell,48 total) helps to increase the probability that groups were equivalent at the outset. A pretest was not feasible since it would be highly reactive with the posttest. Stimulus cards lphysical, mental possible, mental impossible) were counterbalanced to avoid a SERIAL-ORDER BIAS. Audiotaped stories were used and standardized procedures for administering the judgment task were followed.

Differences in performances among subjects is partially reduced by using a within factor; and subject differences are generally controlled by random assignment.

To reduce the tendency of children to communicate the content of the task to other children (hence influencing 
internal validity) of a more salient, playful task was conducted at the END each session. This task was not part of the experiment. The task was tossing a bean bag into a wooden frame or a similar activity. This physical activity is meant solely to provide a more exciting and salient activity that will have a greater probability of being chatted about as opposed to the more sedate stories and questions.

Since the researcher was assuming a short range environmental effect would be effective above the child's natural environmental influences, she made the fantasy story more explicit to be a more powerful influence. The stories are equivalent in length and parallel in content.

The current study was designed to rule out criticism of Koutsourais' study (1984). It thus deals with concretes daily encountered by children (e.g., a soft kitty, a browniel, not higher level abstractions such as evaporation.

Also, unlike Koutsourais' study, the researcher was not looking for short range generalizability of reality status within a child's responses, but group differences across children. Koutsourais approached the problem hoping that children would generalize their knowledge across situations.

wellman and Estes (1986) looked at children's 
ability to differentiate the physical realm from the mental realm; the mental impossible from the mental possible. The current study used their empirical data as a base and focused on whether the environment could differentially affect the abilities they found in voung children. The current control group is an adapted version of their study and the current stimulus and DV response questions are based on their format.

\section{Experiment 1: Story Type with Judgment Task}

\section{Results}

A mixed factorial analysis of variance was conducted to test for the effects of an environmental influence (story type: fantasy, reality, no story) on causal thinking (i.e., a subsequent multilevel judgment task). This addresses the first hypothesis. There were two between factors (story type and experimenter) and one within factor (judgment task). The dependent variable was the percentage of questions answered "yes" on the yes/no judgment task.

Results of the mixed ANOVA did not show the expected interaction between story type and judgment task (see Table 2). The analysis revealed one significant interaction between judgment type (physical, mental possible, mental impossible) and the individual experimenters, $F(2,84)=11.47$, $p<.05$. The Tukey test showed significant differences on the children's responses between the physical and mental realm, 
$p<.05$. No significant differences were found between the mental possible realm and the mental impossible realms, nor were they expected. The significant Tukey results were the same for both experimenters.

Table 2

ANOVA

Story $x$ Experimenter $(x$ Judgment $)$

Source of variation df Sum of Squares Means squared $E$

\begin{tabular}{lrrrr} 
Story & 2 & 1566.2977 & 783.1488 & .48 \\
Experimenter & 1 & 11849.2296 & 11849.2296 & $7.24 *$ \\
Story x Experimtr & 2 & 10280.4904 & 5140.2452 & 3.14 \\
S/ Story Experimtr & 42 & 68758.1380 & 1637.0985 & \\
\hline Totals & 47 & 92454.1557 & & \\
\hline Judgment & 2 & 53550.3472 & 26775.1736 & $46.23 * *$ \\
Judgment Story & 4 & 3015.4080 & 753.8520 & 1.30 \\
Judgment Experimtr & 2 & 13283.4201 & 6641.7101 & $11.47 *$ \\
Judgment Story Exptr & 4 & 3871.5278 & 967.8819 & 1.67 \\
SxJudgmt (StoryxExpt) & 84 & 48649.0885 & 579.1558 &
\end{tabular}

Total

143214823.94748

The main effects of both the judgment task and the experimenters were also significant. For the judgment task results were $F(2,84)=42.26, p<.05$; for the experimenters the results were $F(1,42)=7.24, p<.05$. From the graphs below it can be seen that children could clearly distinguish physical status from mental status. It can also be seen that the experimenters showed similar effects across the judgment tasks but there was also a significant difference between experimenters. 
Figure 1

Mean Proportion of "yes" answers as functions of judgment and experimenter factors.

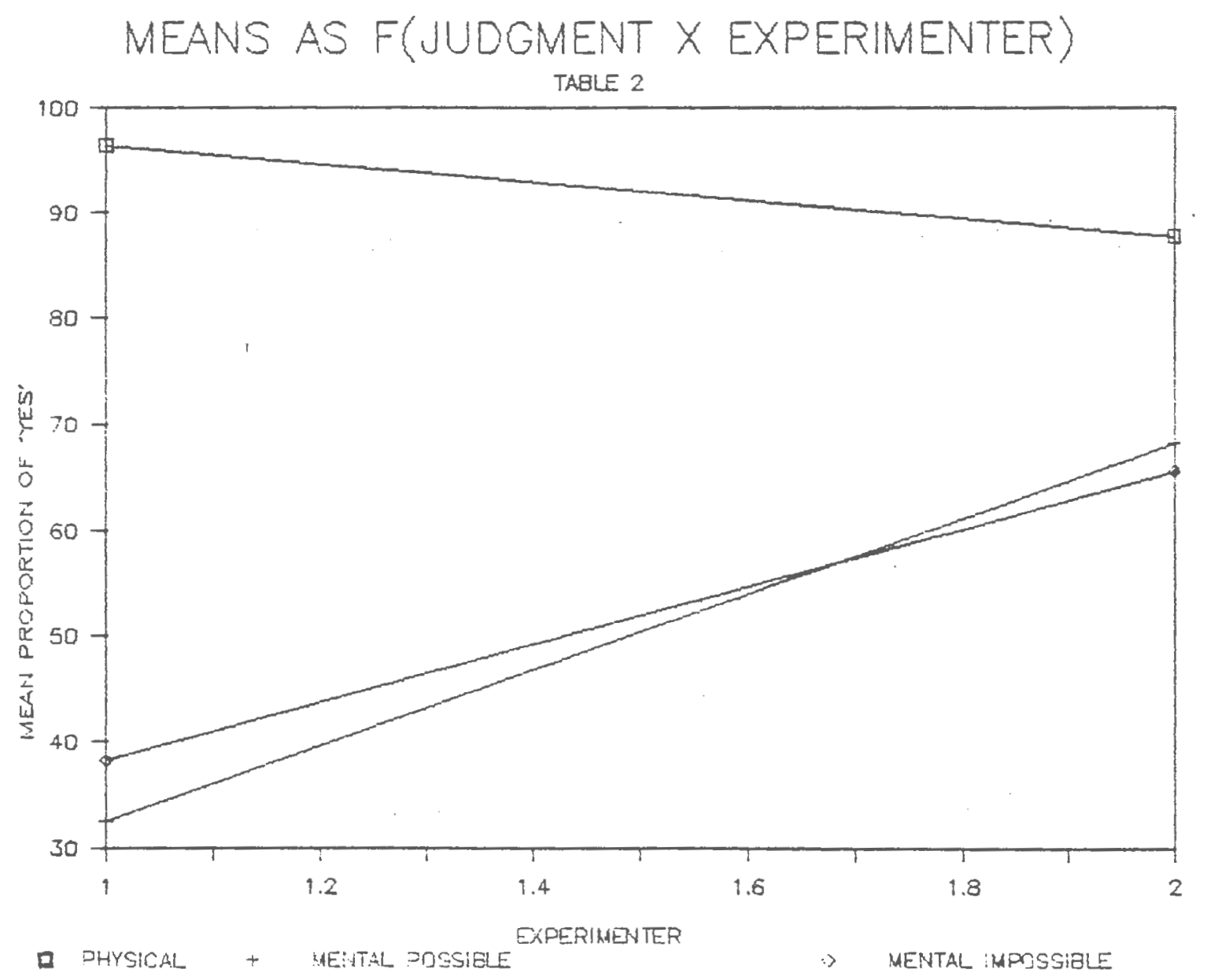




\section{Figure 2}

Mean Proportion of "yes" answers as functions of experimenter and judgment factors.

\section{MEANS AS F(JUDGEMENT X EXPERIMENTER $)$}

TABLE 3

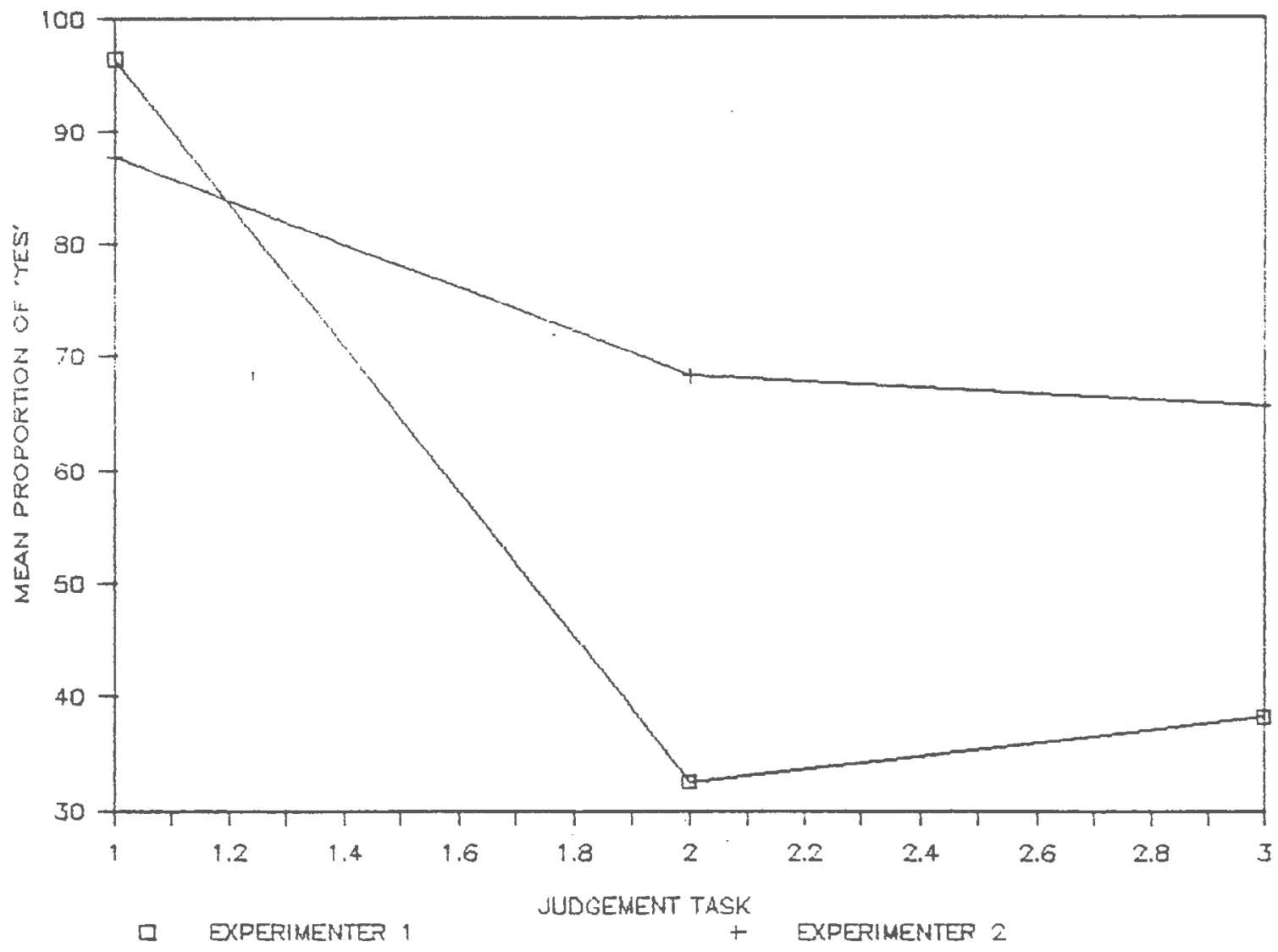

The mean dependent variable (proportion "yes") for this two way interaction ranged from 32.5521 to 96.354 . The mean scores are listed in the means table (Table 1 ). 
Table 3

Mean Proportion "yes" in the Two-Way Interaction

(Judgment $x$ Experimenter)

$\begin{array}{ccccc}\text { Experimenter } & N & \text { Physical } & \text { Judgment } \\ \text { Mental } & \text { Mental } \\ \text { possible } & \text { impossible } \\ 2 & 24 & 96.35 & 32.55 & 38.28 \\ 2 & 24 & 87.76 & 68.23 & 65.62\end{array}$

Note: Higher means indicate children perceive the topic of the item as having a physical status.

From the graphs it appears that significant differences might be found between the physical and the two mental judgment task conditions (Figure 1). Significant differences would also be anticipated between the two experimenters on the mental conditions (Figure 2). This was confirmed by simple effect analysis and Tukey follow up tests.

Simple effects analysis of the judgment task indicate significant results for judgment at experimenter 1 , $\mathrm{F}(2,46)=43.68, \mathrm{p}<.001$ and for judgment at experimenter 2 , $\mathrm{F}(2,46)=6.72, \mathrm{p}<.01$ (see Table 4 below).

Table 4

Analysis of the Simple Effects involving Judgment (Within factor)

\begin{tabular}{lrrrr}
\hline Source & df & Sum of Squares & Mean Square & $F$ \\
\hline J at e1 & 2 & 59807.94 & 29903.97 & $43.68 * * *$ \\
$\mathrm{~J}$ x S/E1 & 46 & 31494.14 & 684.66 & \\
\hline $\mathrm{J}$ at e2 & 2 & 7025.82 & 3512.91 & $6.72 * *$ \\
$\mathrm{~J}$ x S/E2 & 46 & 24041.88 & 522.65 &
\end{tabular}

\footnotetext{
*Fcritical value $(2,46)=3.17, \mathrm{p}<.05$

$* * \mathrm{Fcv}(2,46)=5.13, \mathrm{p}<.01$;

$* * * \operatorname{Fcv}(2,46)=8.13, \mathrm{p}<.001$.
} 
The follow up Tukey tests (Table 5) further illuminate these differences. With both experimenters the children gave significantly more "yes" answers in the physical status than they did in either the mental possible or the mental impossible, showing that they were distinguishing the physical from the mental realm. Also, they showed no significant differences in the mental categories; the study was not designed to tease out such differences, so that these results also are consistent with the fact that overall, the children could distinguish the mental (both categories) from the physical realm.

Table 5

Tukey Test: Pairwise Comparisons of Means

$\frac{\text { Tukey for } J \text { at } e 1}{j 1}$

j1 -

j2 $58.07-$

j3 $63.80 \quad 5.73-$

$\dot{\mathrm{d}} \mathrm{T}=18.32, \quad \stackrel{*}{\mathrm{p}} .05$

j1=physical j2=mental possible j3=mental impossible Note: dT is the summary statistic of the Tukey test. $\frac{\text { Tukey for } J \text { at } \frac{e 2}{j 1}}{j 2}$

$j 1-$

j2 $19.53-$

j3 $22.14 \quad 2.61-$

$\frac{*}{\mathrm{dT}=16.01, \mathrm{p}<.05}$

Analysis of the simple effects of experimenter indicate that no significant differences were found on the physical judgment task (see Table 6). Significant differences were found for both mental tasks; for the mental possible condition, $F(1,46)=10.22, p<.01$ and for the mental impossible condition, $F(1,46)=6.002, p<.05$. 
Table 6

Analysis of Simple Effects involving Experimenter (between factor)

\begin{tabular}{lrccc}
\hline Source & df & Sum of Squares & Mean Square & F \\
\hline E at $j 1$ & 1 & 886.2304 & 886.2304 & .59 \\
S/EJ & 46 & 68758.138 & 1494.7421 & \\
\hline E at j2 & 1 & 15274.25 & 15274.25 & $10.22 * *$ \\
S/EJ & 46 & 68758.138 & 1494.7421 & \\
\hline E at j3 & 1 & 8971.9 & 8971.9 & $6.002 *$ \\
S/EJ & 46 & 68758.138 & 1494.7421 & \\
\hline FCv $(1,46)=4.06, p<.05$ & Fcv $(1,46)=7.25, p<.01$
\end{tabular}

The omega squared results (treatment magnitude) indicate that $5.6 \%$ of the variability observed is explained by the judgment $x$ experimenter interaction. This is a relatively small effect. Judgment alone accounts for $24.2 \%$ of the variablilty, a large effect, whereas the experimenter accounted for $10.85 \%$ of the observed variability, a large effect.

Experiment 2: Reality, Mental-Possible, Mental-impossible Probe

Results

This experiment addresses the second hypothesis, that young children are capable of differentiating fantasy from reality; the physical from the mental possible and the latter from the mental impossible. For all judgment levels, children correctly answered questions 5 and 6 assessing reality status and the ability to think about the entities 
discussed. Responses to both questions greatly exceeded a chance value of $50 \%$. For question 5 (Have have you ever really SEEN a __? children answered respectively for physical, mental and mental impossible responses, $98 \%, 96 \%$, $91 \%$ correct $1 \mathrm{y}$.

For question 6 (Could you close your eyes and THINK about _? children answered respectively, for physical, mental possible and mental impossible conditions, $89 \%, 82 \%$, $82 \%$ correctly. Four year olds on these questions demonstrate a clear ability to differentiate physical status from mental status. (See Figure 3 and Table 7)

Table 7

Physical Mental-possible Mental-impossible

\begin{tabular}{clclccc} 
& $\begin{array}{c}\text { CARDS } \\
\mathrm{A}+\mathrm{B}\end{array}$ & $\begin{array}{c}\% \\
\text { correct }\end{array}$ & $\begin{array}{l}\text { CARDS } \\
\mathrm{C}+\mathrm{D}\end{array}$ & $\begin{array}{c}\% \\
\text { correct }\end{array}$ & $\begin{array}{c}\text { CARDS } \\
\mathrm{E}+\mathrm{F}\end{array}$ & $\begin{array}{c}\% \\
\text { correct }\end{array}$ \\
\hline $\begin{array}{c}\text { Question } \\
5\end{array}$ & $\begin{array}{l}\mathrm{O}=94 \\
\mathrm{E}=48 *\end{array}$ & $98 \%$ & $\begin{array}{l}\mathrm{O}=92 \\
\mathrm{E}=47.5 *\end{array}$ & $96 \%$ & $\begin{array}{l}\mathrm{O}=9 \\
\mathrm{E}=48 *\end{array}$ & $91 \%$ \\
\hline $\begin{array}{c}\text { Question } \\
6\end{array}$ & $\mathrm{O}=86$ & $89 \%$ & $\mathrm{O}=79$ & $82 \%$ & $\mathrm{O}=79$ & $82 \%$ \\
$\mathrm{E}=48 *$ & & $\mathrm{E}=48 *$ & & $\mathrm{E}=48 *$ & \\
\hline
\end{tabular}

$\mathrm{E}^{*}=$ the expected chance response frequency of sample $(50 \%)$

$\mathrm{O}=$ the observed frequency 
Figure 3

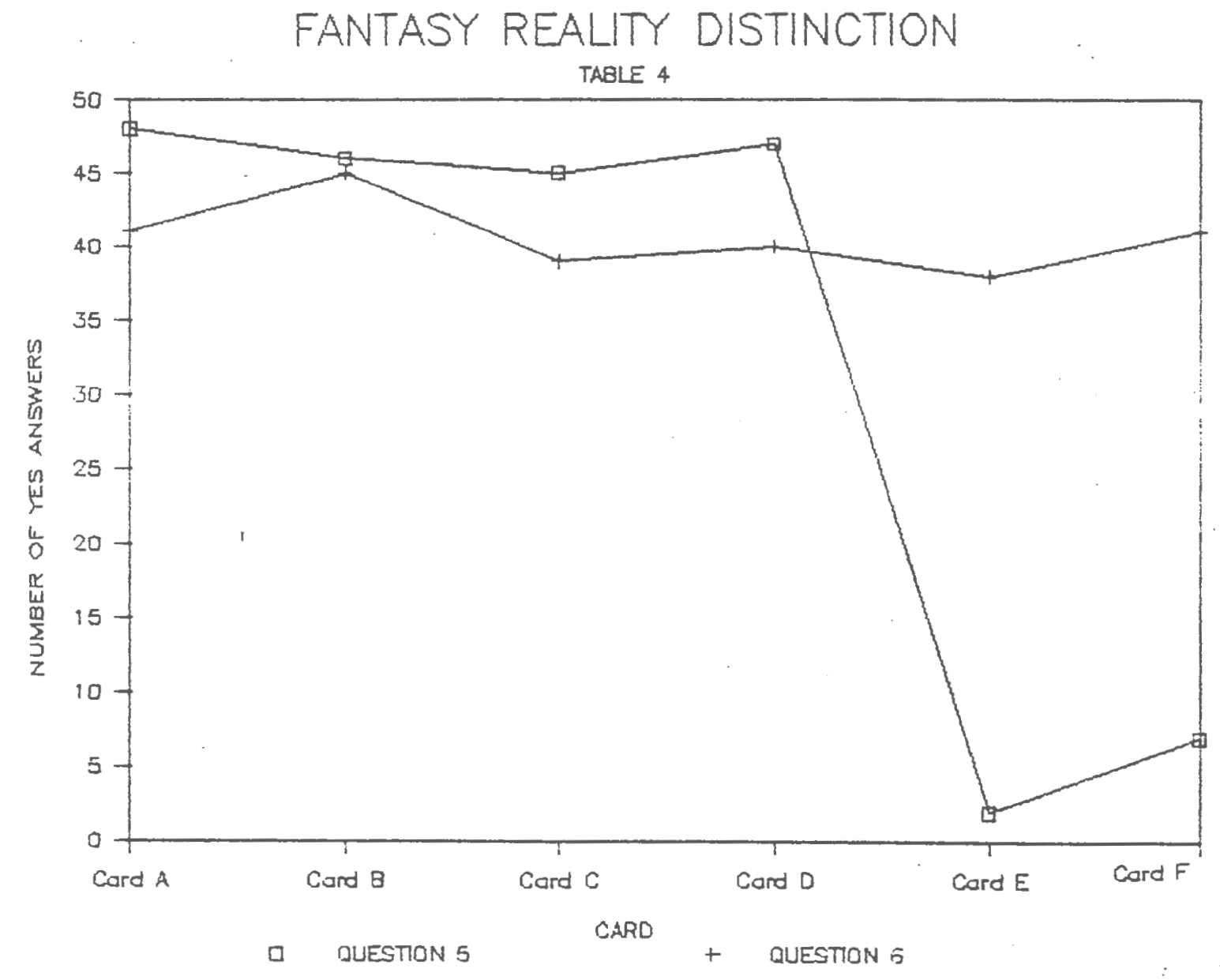

Note: Cards A\& B were physical; Cards $C$ \& $D$ were mentalpossible; Cards $E \& F$ were mental-impossible (fantasy) 


\section{Categories of Explanation}

Children's verbal responses showed a range of understanding on the differences between physical entities and mental entities, both possible and impossible (fantasy). Responses were grouped into 6 broad categories according to Wellman and Estes groupings (1986, see Appendix G).

Table 8

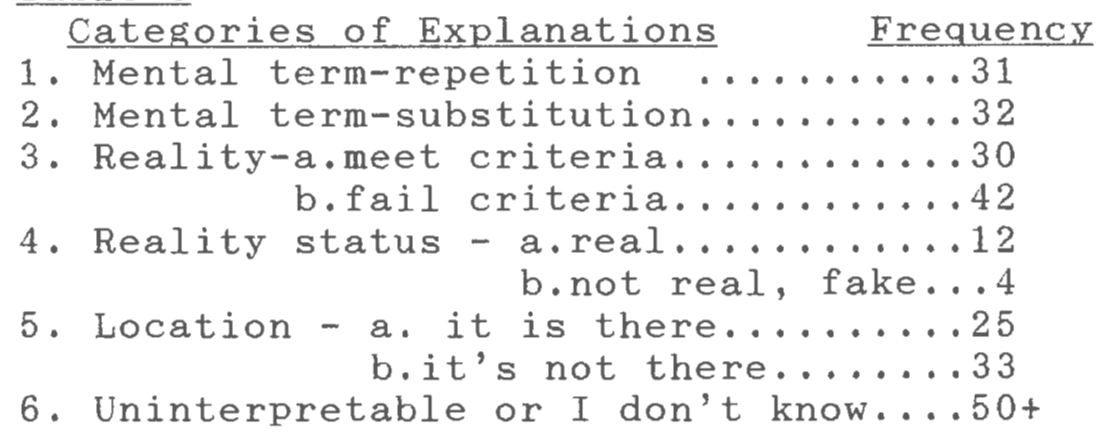

The actual responses are in Appendix $H$. Some children gave many responses and others gave none so this chart is only giving a rough estimate of the types of responses found and their distribution. It was interesting that children used different mental verbs spontaneously (Mental term -substitution) such as dreaming, imagining, in my mind, in my head. It is also noteworthy that not many children actually said "It's real" or "It's fake" (reality status category). Some of the responses were striking such as the following:

"Your mind can think about anything it wants to."

"Because Darlene is thinking of it, not her friend"

"Because no friends can see in other people's minds."

"Because he's thinking of it and the other person can't see it."

"Cuz if it were in both minds they could see it." 
"Not if it's dancing, that would be a cartoon."

"Not if she's thinking of it cuz it's just her imagination."

"That would be funny, a little bicycle - there's no such thing."

These type of responses do reveal the four year old child's ability to use mental terms with good understanding. There were also some responses, but not many, that showed a child's confusion, e.g.,"I know a man who can turn into a car." 


\section{Discussion}

Children performed at high levels on the physical condition of the judgment task meaning that when asked questions such as "Right now Susie has a cookie, can she touch it with her hands... see it with her eyes...can her friend see her cookie... can she save her cookie and eat it tomorrow", the children gave correct affirmative answers.

When asking the same type questions but using a mental verb, (e.g., Susie is THINKING about a cookie...) the children's responses showed a significant drop from the physical condition reflecting that they were making distinctions between the physical and mental realms.

Two experimenters independently ran children in the study and with both experimenters, the children showed the same ability to distinguish the physical from the mental realms. However, the experimenter blind to the study showed this ability to a significantly lesser degree. To examine why one experimenter, blind to the study, had subjects whose responses supported the hypothesis that children can distinguish the physical from mental realms but not as clearly so as the original researcher, the children's verbal responses were examined. Experimenter bias is one possible explanation. From examining notes on the verbal responses and elaborations of the children during the judgment task, it seems that the primary researcher was able to tap into 
the children's ability better. For example, where the pattern of responses was found to consistently support the idea that children can very clearly tell the difference between thinking and having, different children of experimenter 1 gave the following elaborations:

Cuz thinking is only in the imagination.

Because it's inside of him, he's thinking.

Because he doesn't have it.

Not if she's thinking of one, cuz it's just in her imagination.

Because she's just thinking about it.

only if that friend is thinking about the apple that dances too.

Cuz she's thinking of it.

Because he's thinking of it and the other person can't see it.

Because it's not there.

Because no friend can see in other people's minds.

Because she's just thinking about it.

These responses further strengthen the notion that the above children who answered in these accurate patterns did indeed demonstrate their ability to distinguish thinking from having.

The researcher blind to the study did not tend to stress the words "thinking" and "has" and as consistently as experimenter 1 , and this seemingly slight administrative change might partially contribute to significant differences across experimenters. Perhaps the children's FOCUS was thus not directed as clearly to the thinking/having distinction and the children answered more randomly. When looking at the verbal responses in experimenter 2's subjects who did not have the accurate pattern, there is evidence for this 
speculation. (The list of verbal responses is in Appendix H. )

In doing this type of a study, the issue of focusing the child's attention seems to be of fundamental importance in order to obtain responses from the children that most accurately reflect their abilities. There were several potential confounding factors that the researcher had to occasionally work to overcome. These included the child's competing activity in the classroom at the time that the experimenter approached the child (e.g., snacks, recess); another factor was the manner in which the child's teacher introduced the experimenter; yet another was the fact that the experimenter was a new person introducing the child into a novel situation. Also, the "least distractable areas" varied across schools - some were noisier than others.

Within the task, the use of the taperecorder seemed to work especially well and the length of the story for this task (about a minute and a half) was ideal for the child's attention span - there were no children who objected to this procedure.

The ease in administrating the 36 questions varied; there were some children who were easy to engage and talked very freely and could have gone on with even more questions; other children seemed to find the questions more difficult to attend to for the duration, e.g., focusing a shy child's attention for this duration was straining. There was also 
the occasional problem of wondering what aspect of the question the child was focused on; an occasional child would answer as if he or she was attending to a word, say cupcake or dog, and not the the physical mental distinctions. As a result the child would answer tangentially talking about cupcakes they had at home or talking about their dog, such that their answers were not necessarily tapping their ability to distinguish physical from mental.

One last potential confound was that the probe "If she wanted to, could she SEE it with her eyes?" seemed to cause more confusion than other probes, and it was realized that even adults use the word "see" often to refer to mental ideation, e.g., "I SEE what you mean", "I can really SEE that."

To deal with some of these critiques of the current study, especially regarding the experimenter differences, it is suggested that very clear standardized rules are put forth to guide the experimenters under what circumstances and how they are to deal with the different difficulties of FOCUSING the child's attention. Pre-test training is highly advised and perhaps the primary researcher should not be involved in order to rule out the possibility of experimenter bias. Focusing the child's attention to the appropriate aspects of the task are fundamental if this methodology is to have validity.

The fact that story type had no effect was surprising. 
It seems that the children's reality testing in this sample was more resilient to short term fantasy influences than the researcher had considered. Indeed, many of the verbal responses reinforce the fact of the children's clarity and only a small number of responses indicated a confusion about reality status (e.g., "I know a man who can turn into a car."). Given that the overwhelming majority of books, movies and television shows noted (in Appendix I) as favorites by the parents were fantasy based, it is impressive that four-year olds have been able to gain clarity between reality and fantasy. One suggestion for future research would be would be to employ stories that varied in content from simple fantasy-reality testing (e.g., about a cat) versus content that is more affect laden and encouraged by adults (e.g., about Santa claus). This might help to further fine tune both the role of environmental influences and children's ability to distinguish fantasy from reality.

Further dramatic evidence of the child's ability to gain clarity between reality and fantasy can be seen in the second experiment. When children were asked two questions at the end of each judgment, (six per child), their responses were illuminating. When asked "Can there really be an (entity discussed on card)?", they answered "yes" correctly across cards A \& B (physical status) $98 \%$ of the 
time, "yes" correctly across cards C \& D (mental possible status) $96 \%$ and "no" correctly across cards E \& F (mental impossible) $91 \%$ of the time- indicating that indeed they knew that there could, for example, never be an apple that dances or an ant that rides a bike. However, when asked if they could close their eyes and think about each situation, the children that said "yes" they could think about things that existed (physical condition, $89 \%$ answered correctly); that were in the mind but could exist (mental possible, $82 \%$ ) and that were in the mind but could never exist (mental impossible, $82 \%$ ). Thus, the vast majority of children knew that ants riding bikes and apples that dance can't really exist (91\%) yet they realized they could close their eyes and think about such scenes, (82\%). Their ability to make the distinction between the mental possible and the mental impossible is a finer distinction than the distinction between the physical and mental realms.

Theoretical Implications

Piaget's theory places child's ability to distinguish fantasy from reality at about the ages of 6 to 7 and thus the role of the environment has less impact. Rand's theory holds that the child notes similarities and differences among its experiences from its youngest years and that the child's ability to categorize and integrate its experience 
depends on the amount of experience and the amount of mental integration done and the environmental encouragment or discouragment of his or her ability to differentiate and integrate its knowledge (1968/1975, 1979).

Rand's (1979) and Kelly's views (1984, 1986, 1986 cassette recording) seem to offer a better fit to the cumulative research presented in this paper, including the current study. However, it is to be strongly noted that although the current study showed that 4 year olds can distinguish the mental from the physical realms, it did not specifically address other aspects encompassed in the theories and in some of the literature mentioned. These other aspects, including the impact of encouraging belief or disbelief in fantasy, are fertile areas for continued study.

The cumulative literature supports the need for a theory that better accounts for all the evidence. Specifically, two studies (Prentice, Schmechel \& Manosevitz, 1979 and Lesser \& Paisner, 1985) suggest a potentially important explanation for why the environmental influence in the current research had no effect. The authors of these articles suggest that most children and adults, as they mature, are able to deal more naturalistically with their mental contents and with their world. However when external pressures to maintain belief in non-naturalistic thinking are operative, the affective conflicts and incentives working against relinquishing such beliefs may make 
naturalistic causal reasoning more difficult. Prentice, Schmechel \& Manosevitz (1979) suggest this in the following quote:

Clearly, a number of children who are more advanced in cognitive maturity maintain their belief in santa Claus. Presumably some children retain their belief in the face of LOGICAL INCONSISTENCIES simply because the INCENTIVES FOR BELIEF ARE SO GREAT. The child may be persuaded by the parents to retain belief in santa while at the same time he is being rewarded by them for relinquishing other types of magical thinking. Gould (1972) asserts that as children mature, they normally manifest an ability to deal more objectively in all realms of interaction with their world, as well as in their mental life. However, where certain AFFECTIVE CONFLICTS are present, 'the gradations and distinctions achieved in causality comprehension emerge more slowly and are less stable than in impersonal, objectively-structured situations.' (Gould, 1972, p. 58 )" (Prentice, Schmechel, Manosevitz, 1979, p. 666, emphasis added)

Given these ideas, why did the current study fail to support the idea that fantasy and reality environmental influences would have differing effects? In both conditions the children were able to differentiate fantasy from reality in the ensuing judgment task. One answer is that my theory is wrong and perhaps children are not as effected by the environment, perhaps they are more biologically determined.

Another explanation might be that a one and a half minute story was not enough of an environmental effect to compete with four years of a child's personal experience with the environment. Children across all story groups could differentiate physical from mental phenomena and possible mental phenomena from impossible mental phenomena 
(i.e., fantasy). Also, the questions in the judgment task did not relate to the story and this may have hindered seeing any short-range effect that the story might have had. The ensuing judgment task questions were very down to earth simple questions which seemed to do a very good job at tapping children's actual abilities but perhaps did not isolate possible cognitive, affect-laden situations when children tend to become more confused about the reality status or what actions they should take in a situation.

So the question remains open: How does one explore the effect of environmental influences vis a vis fantasy/reality differentiation on children's thinking processes - or is there no effect. One suggestion is to change the type of questions asked in the judgment task to relate more directly to the story content. Another suggestion is to do some naturalistic studies of groups of children differing more long range in their upbringing (across belief systems) regarding fantasy, magical beliefs, etc. Several studies have been done along these lines, for instance exploring parental encouragement of mythical figures (e.g., Santa Claus) as Prentice and colleagues (1978) have done, and looking at childrearing styles and the effect on children (Sigel, ed, 1985).

Perhaps a more extreme contrast would be to look at preschool children who either have a reality oriented schooling (e.g., the Montessori approach) versus a 
dogmatic/authoritarian mystical approach. Also a cultural or historical study could be done looking at the thinking processes of children across cultures and history.

Finally, it might be interesting to test a group of children using several stories or judgement tasks that vary in the emotional attachment to certain beliefs (such as stories about a kitten versus stories about Santa Claus).

The current approach was meant to be an extension and improvement over the approach used by Koutsourais. She used an explanation of a remote occurrence, evaporation, to gauge the child's reality oriented capacity. The content of my story was intentionally made simple (two children playing with a kitten) to adequately tap the child's true ability. As discussed above it is time to return to the drawing board to further refine a method to explore this hypothesis. 


\section{REFERENCES}

Barnes, H. \& Lyons, N. (1986). Education as an art: The Rudolf Steiner method. Massachusetts: Association of Waldorf Schools.

Berzonsky, M. (1971). The role of familiarity in children's explanations of physical causality. Child Development, $42,705-715$.

Brainerd, C.J. (1978). Piaget's theory of intelligence. New Jersey: Prentice-Hall.

Bringuier, J. (1980). Conversations with Jean Piaget. Chicago: University of Chicago Press.

Campbell, S. (Ed.). (1980). Piaget Sampler: An introduction to Jean Piaget through his own words. New York: John Wiley \& Sons.

Collyer, C. E. \& Enns, J. T. (1987). Analysis of Variance: The basic designs. Chicago: Nelson-Hall.

Dworetzsky, J. (1984). Introduction to child development. New York: West Publishing Co.

Estes, D., Wellman, H., \& J. Woolley. (in press). Child's understanding of mental phenomena. Manuscript submitted for publication. To appear in $\mathrm{H}$ Reese (Ed.), Advances in child development and behavior, vol. 21 .

Inhelder, B. \& Piaget, J. (1958). The growth of logical thinking: From childhood to adolescence. New York: Basic Books.

Inhelder, B., Sinclair, H. \& Bovet M. (1974). Learning and the development of cognition. Massachusetts: Harvard University Press.

Kelley, D. (1984). A theory of abstraction. Cognition and brain theory, VII( $3 \& 4)$, summer/fall.

Kelley, D. (Speaker). (1986). The nature of freewill (cassette recording) Toronto: The Portland Institute.

Kelley, D. (1986). The evidence of the senses. Baton Rouge, Louisiana: Louisiana State University Press.

Keppel, G. (1982). Design and analysis (2nd ed). New Jersey: Prentice-Hall. 
Koutsourais, H. (1984). Inhibiting magical thought through stories, Child Study Journal 14, 227-236.

Lesser, R. \& Paisner, M. (1985). Magical thinking in formal operational adults. Human Development 28, 57-70.

Modgil, S. \& Modgil, C. (1976). Piagetian research: Compilation and commentary (Vols. 1-8). Great Britain: NFER Publishing.

Montessori, M. (1965). Dr. Montessori's own handbook. New York: Schocken Books.

Morison, P. \& Gardner H. (1978). Dragons and dinosaurs: The child's capacity to differentiate fantasy from reality. Child Development, 49. 642-648.

Phillips, D. (1982). Perspectives on Piaget as Philosopher: The tough, tender-minded syndrome. In Modgil, S. \& Modgil, C. (Eds.) Jean Piaget: Consensus and controversy. (pp. 13-29). Praeger Special studies, Praeger scientific.

Phillips, J. (1975). The origins of intellect: Piaget's theory. San Francisco: W.H. Freeman \& Co.

Piaget, J. (1929). The child's conception of the world. London: Routledge and Kegan Paul Ltd.

Piaget, J. (1951). The child's conception of physical causality. London: Routledge \& Kegan Paul Ltd.

Piaget, J. (1952). Judgment and reasoning in the child. New York: Humanities Press.

Piaget, J. (1962). Play, dreams and imitation in childhood. New York: Norton \& Co.

Piaget, J. (1972). The principles of genetic epistemology. New York: Basic Books.

Piaget, J. (1971). Psychology and Epistemology. (A. Rosin, Trans). New York: Grossman Publishers. (Original work published in 1970).

Piaget, J. (1972). The principles of genetic epistemology. (W. Mays, Trans.). New York: Basic Books. (Original work published 1970).

Peikoff, L. unpublished lectures given during sundry conferences. 
Prentice, N., Manosevitz, M., \& Hubbs, L. (1978). Imaginary figures of early childhood: Santa Claus, Easter Bunny, and the Tooth Fairy. American Journal of Orthopsychiatry, 48(4), 618-628.

Rand, A. (1968/1975). The new left: The anti-industrial revolution. New York: New American Library.

Rand, A. (1979). Introduction to objectivist episetemology. New York: New American Library.

Randall, T. \& Desrosiers, M. (1980). Measurement of supernatural belief: Sex differences and locus of control. Journal of Personality Assessment, 44(5), 493-498.

Shatz, M. Wellman, H.M., \& Silber, S. (1983). The acquisition of mental verbs: A systematic investigation of the first reference to mental state. Cognition, 14 , $301-321$.

Sigel, I. (1985). Parental belief systems: the psychological consequences for children. New Jersey: Lawrence Erlbaum Associates.

Wellman, H. (1985). The origins of metacognition. In D. Forrest-Pressley, G. Mackinnon, \& T. Waller (Eds) Metacognition, cognition, and human performance (pp. 1-31). San Diego: Academic Press.

Wellman, H. \& Estes, D. (1986). Early understanding of mental entities: A re-examination of childhood realism. Child Development, 57, 910-923. 


\section{APPENDIX A}

Refresher of Piaget's Preoperational Stage

(adapted from Dworetzky's Textbook, ch. 10)

I. Cognitive Development is the result of

A. Genetic development of the nervous system

B. Environmental experiences

(Since most of us have similarities in both of these areas predictable cognitive developmental stages will occur. All children advance through these stages, although the intellectually impaired might go slower or not reach the top stage.)

II. Major terms used by Piaget and their interrelationship A. SCHEMA: An individual's comprehension of the world, like a map or schematic of the world around them and stored in memory. Since children have less well developed cognitive brains structures and less experience, their schemata is QUALITATIVELY different from an adult's schemata.

B. ADAPTATION: The ability to fit in with one's environment.

Two types

1. Assimilation: The act of taking in new information and integrating it into evolving or completed cognitive structures.

2. Accommodation: The process in which a person adjusts the existing schemata or cognitive structure to incorporate new elements in its experience.

C. Equilibration: An innate force that drives children to pursue adaptation which helps bring them through the cognitive development stages. (They resolve discrepancies between existing cognitive structures and experience.।

D. Cognitive stages have the following characteristics: 1. The ages Piaget gives are only approximate. 2. All children go through each stage in the sequence given.

3. In transition between stages, a child may show characteristics of both stages. 4. Older children or adults may opt not to use their higher structures and may rely on lower states of cognition.

5. The stages are epigenetic (including aspects of both genetics and the environment. 
6. Cognitive stages are related to the maturation of cognitive structures in the brain/nervous system.

III. The Preoperational Period (2-7 years) A Characterized by the ability to use internal images and symbols - possibly the beginning of self-awareness and thought.

B. Called "preoperational" because children in this stage have not yet developed the more advanced rules of thought.

C. Two stages within this period:

1. Preconceptual stage (ages 2-4): Immature concepts Two types of reasoning processes:

a. Syncretic: objects are classified by a limited and changing set of criteria - ex. "The hat goes with the bird because they are both blue."

b. Transductive: Inferences about the relationship between two objects is based solely on a single isolated attriute. ex. A is hungry, B is hungry therefore $A$ is $B$. Animistic thinking is common to this stage.

2. Intuitive Stage (ages 4-7): Beliefs are based on what is sensed or imagined rather than logical or rational thought.

Egocentrism: Characteristic of children in this stage where they see the world from their own perspective. 


\section{APPENDIX B}

Definitions of Piaget's Types of Causal Reasoning in Young Children

1. Motivational Causality: A psychological motive is the cause of things. For example, "I fell because Santa is punishing me." "Nightmares are sent to us because we are bad." or "The ball decided to hit the window." Things, such as the ball, are conscious.

2. Phenomenistic Causality: Two unrelated facts happen together in time and space and the child sees them as causally related. For example, "The ball fell because it is red."

3. Finalistic Causality: A description is substituted for causality, without reference to origins, consequences, motives or consciousness. For example, "A tree has leaves because they are part of a tree."

4. Moralistic Causality: Events occur because they have to. For example, "The sun must set so that we can have night." "The ball must bounce so that we can have fun."

5. Magical Causality: One's gestures, words and thoughts can influence people and events, i.e., they can either cause something to happen, or prevent something from happening. For example, "If I wave my magic wand, I can stop dad from spanking me." or "If I think hard enough, I can make Santa give me more gifts."

6. Animistic Causality: Attributing motives and psychological causes to physical phenomena. For example, "Clouds move so that they can get from place to place."

7. Artificialistic Causality: Humans created metaphysical objects. "Men made the sun." 
Appendix $C$

Informed Consent Letter and Parental Questionnaire

Greetings,

As a graduate student in the psychology department at the University of Rhode Island and as a mother of two children, ages six and eight, I have developed an interest in the way children think. My interest has evolved into a master's study designed to assess the thinking abilities of young children (age 4 ).

In the current literature various methods have been used to determine how and when a child learns to distinguish mental phenomena form physical phenomena. Most notable, the prodigious studies by Jean Piaget have sought to answer these questions. In studying and categorizing children's causal explanations, Piaget developed a stage theory of cognitive development. The purpose of the current study is to examine the effect of the environment on children's causal thinking and to validate that "preoperational" children (Piaget's term for a stage children pass through where he proposes that they are incapable of distinguishing mental from physical phenomena) can differentiate mental phenomena from physical phenomena and that they can distinguish fantasy from reality when these distinctions are assessed very concretely.

What this involves is telling the children some simple short stories (e.g., about a dog or a similar animal), showing them some colorful cards of children and asking them some questions (e.g., Can Sandy hear the dog bark?) which will be audiotaped. I will also be doing a short playful activity with them such as tossing a bean bag into a wooden frame.

This area of research has widespread implications. The ideas we have about the developing child's mind influence our childrearing practices, our educational perspectives and ultimately the type of culture, politics and aesthetics that predominate.

If you are interested in having your child participate, complete and return the bottom form. Due to the limited scope of the study, I will only be able to see children age 4. Please be sure to include your child's birth month and year. The study takes about 15-25 minutes total. Parents will be asked to fill out a short questionnaire for research purposes only (demographic information). Once you give consent. I will additionally ask permission of your child. I have planned the study to be fun and interesting for the children.

This study has been approved by the Institutional 
Review Board at the University of Rhode Island. There are no risks or personal benefits involved in this study. The specific material I gather will be kept confidential and will not be shared with anyone outside my research committee. Nursery, day-care or camp personal are not involved in this research. You are free to refuse to participate and in no way will your decision affect your child in day-care, nursery school or camp. I am acting independently as a graduate student from the University of Rhode Island.

If you are interested in having your child participate, please fill out and return the informed consent form below by

$* * * * * * * * * * * * * * * * * * * * * * * * * * * * * * * * * * * * * * * * * * * * * * * * * * * * * * * * * * *$

Thank you for your time and interest. Please feel free to call me if you have any questions (647-5387). If I'm not home, you may leave a message on my answering machine and I'Il return your call.

Thanks,

Ellen Kenner

Informed Consent Form

I, voluntarily give my consent for my child to participate in the above study. My child's age is ___ and his/her birthdate is Year Month -

I understand that this study is for educational purposes. I am free to withdraw at any time and although the material gathered (simple yes/no responses and children's causal explanations) is not personal, my child's individual responses will be kept confidential.

Signature of Parent or Guardian

Date signed

Check here if you want information on or are interested in participating in future studies on this topic. 
Parental Questionnaire

(Please Print)

CHILO:

Child's name

Sex (circle one): Male

Fema le

Preschool or Daycare Experience:

Type of experience Average Frequency/week Age No. of months

Date

Age: Years

Months

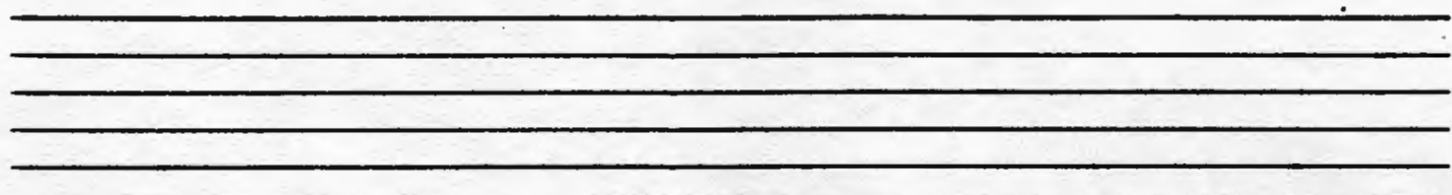

FAMILY:

Please list your other children in order of birth giving their age and sex.; (names are not needed)

Month and year of Birth

Sex

Circle the following which best applies to your situation:

(circle one per question)

1. Single Divorcad 1st marriage Remarried Years married

2. Family setting: Town/city village rural

3. Family income range (approx.)

4. Cultural background:

MOTHER :

Age _ Occupation Week Ty work hours

Education (check one): no formal education

_ some grammar school
- finished 8th grade
- some high school

_ some grammar school
- finished 8th grade
- some high school

_ some grammar school
- finished 8th grade
- some high school

rusa

FATHER :

Age Occupation Education (check one):

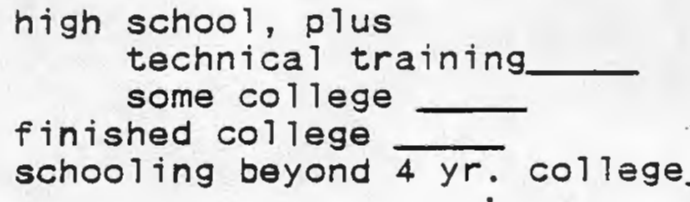


Child's name

Please list your child's favorite books, movies and television programs.

Books

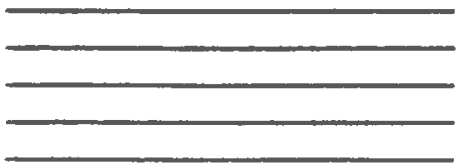

Movies

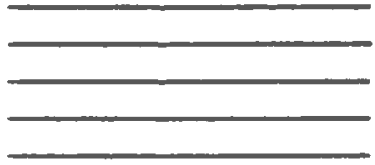

Television Programs

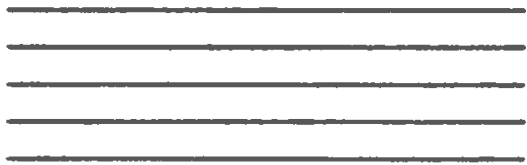


Appendix E

Demographic Graphs

SIELING INFORMATION

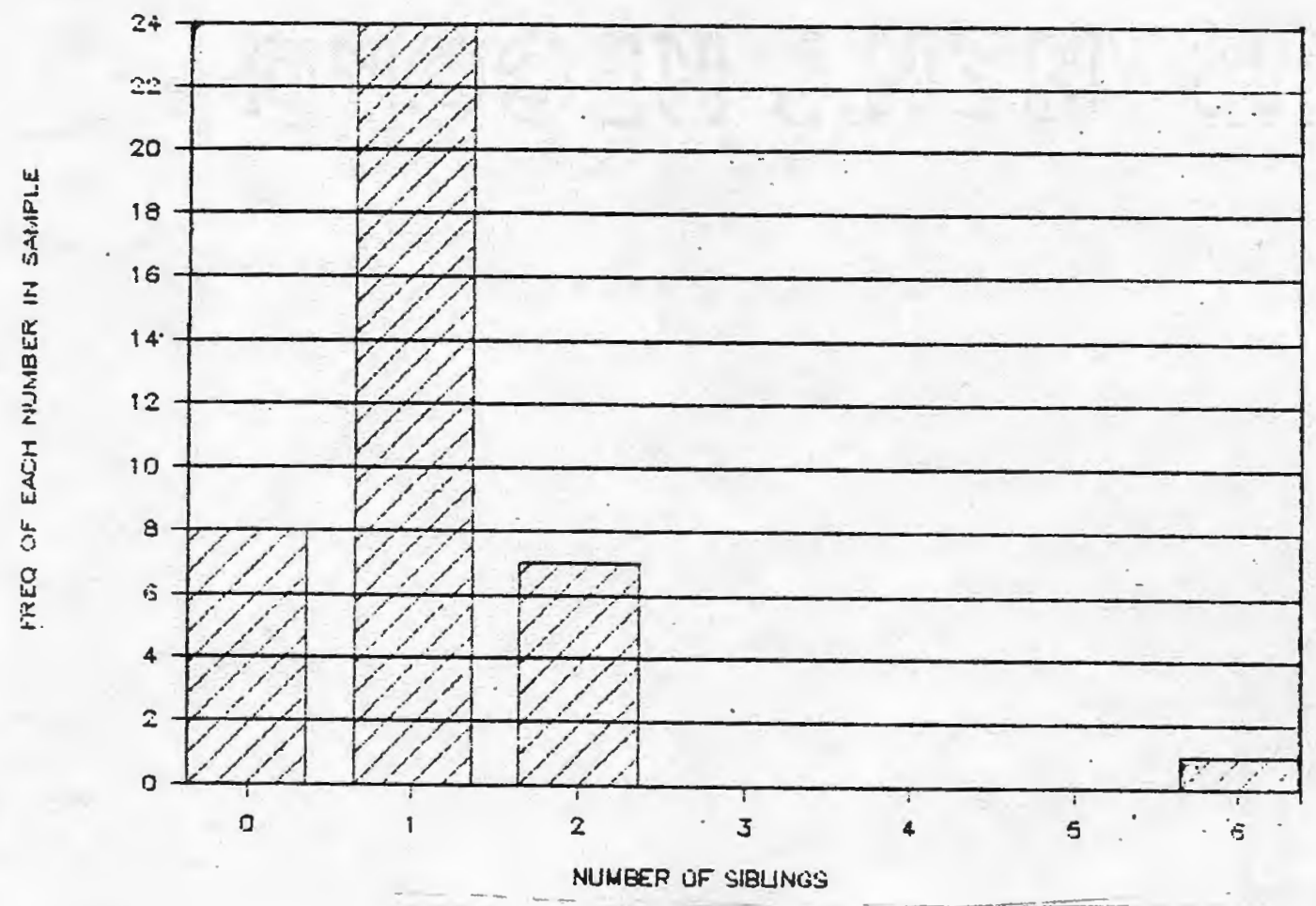

MARITAL STATUS

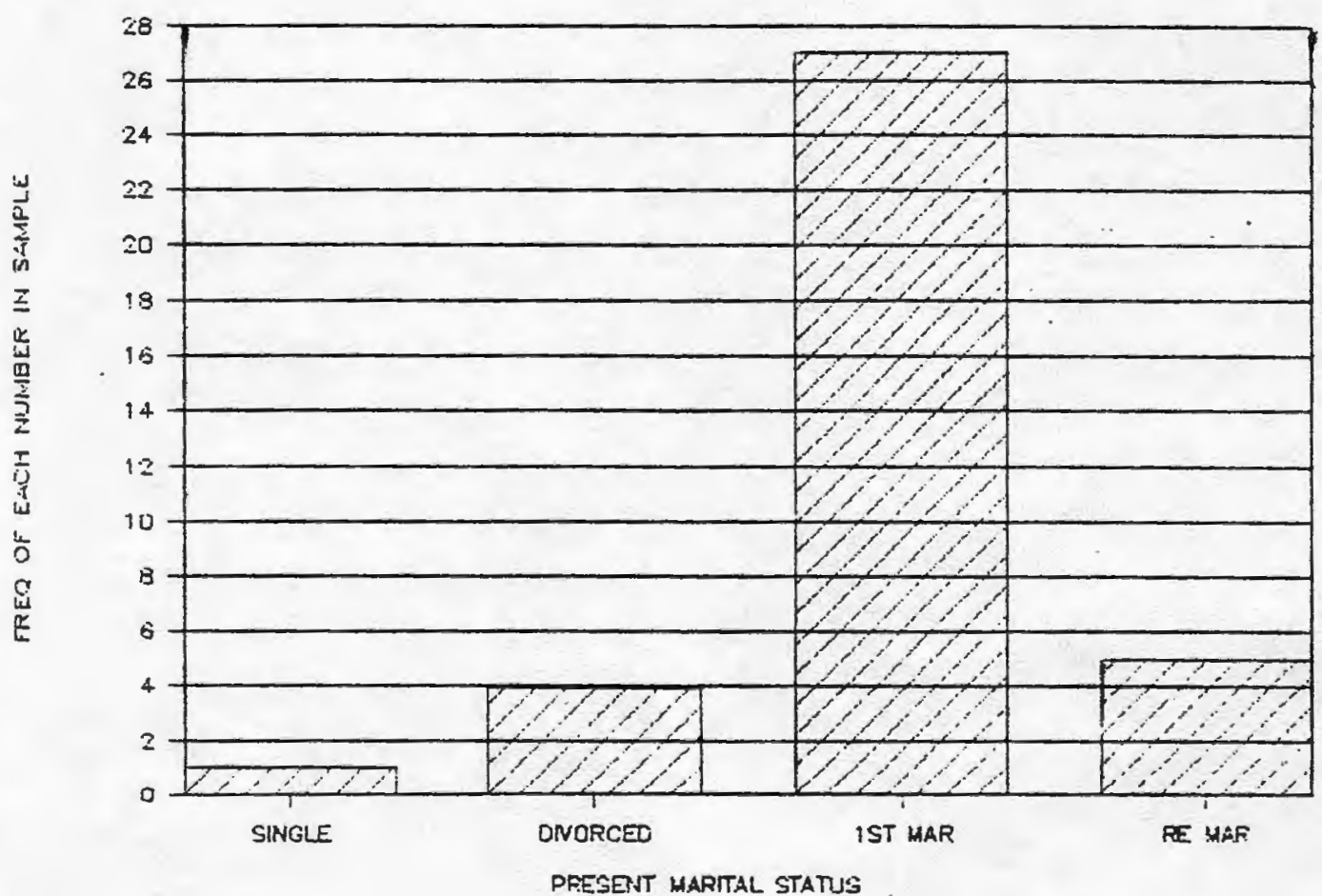


Appendix $E$

Demographic Graphs

NEIGHBORHOOD SETINNG

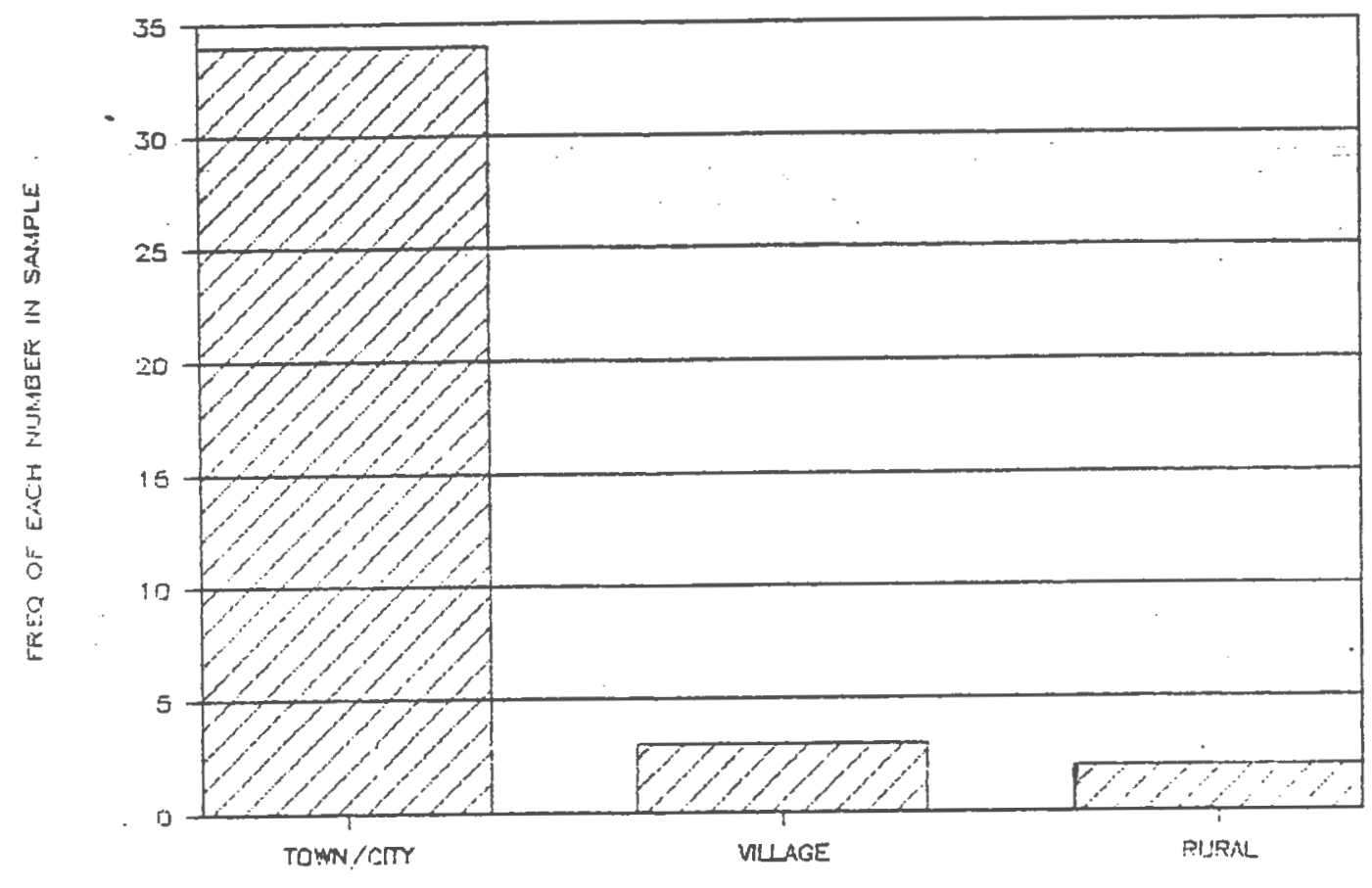

NEGHBORHOOR 'ETTIAGS

PARENTS EDUCATION

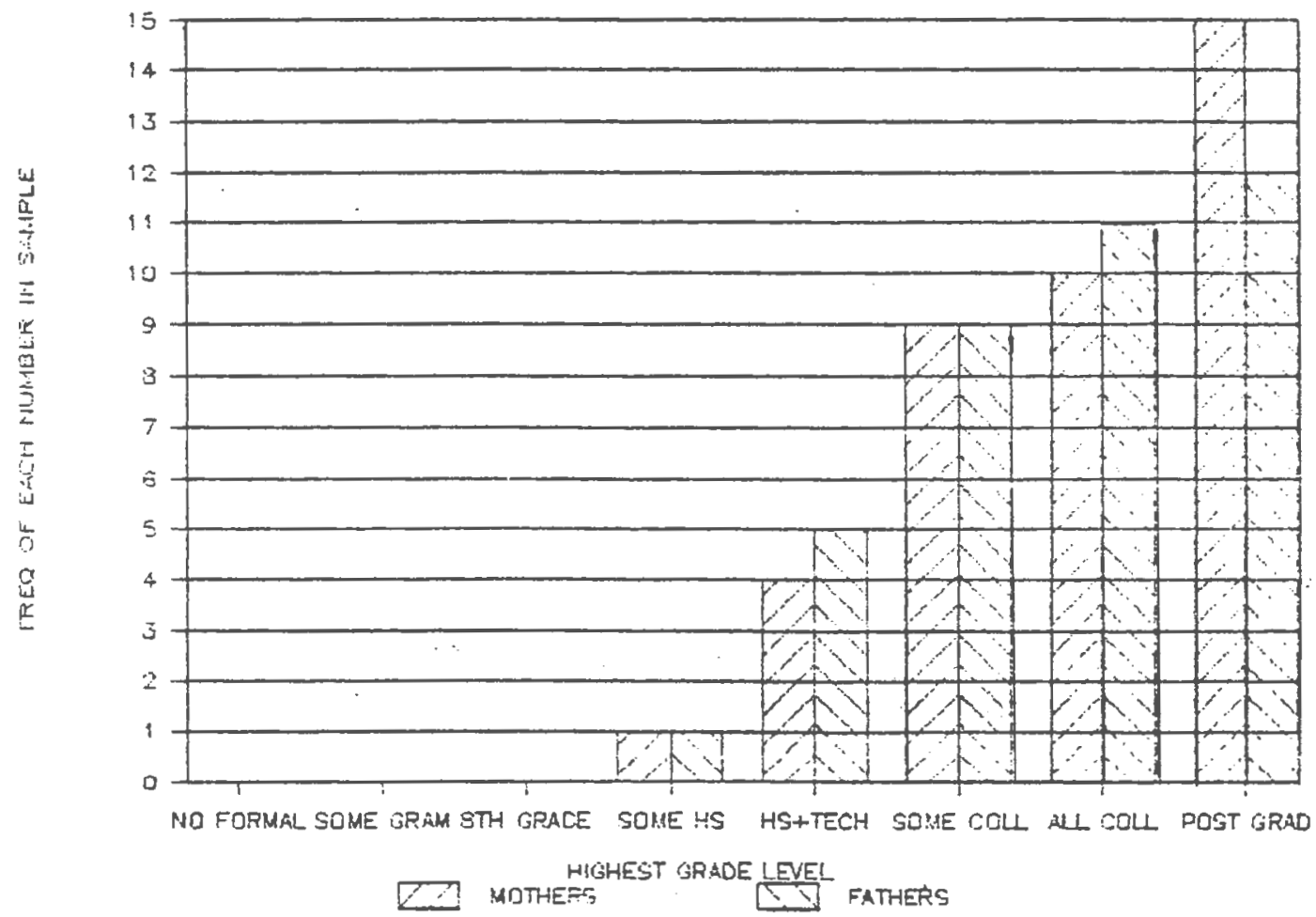


Appendix E

Demographic Graphs

WEEKLY HOURS AT WORK

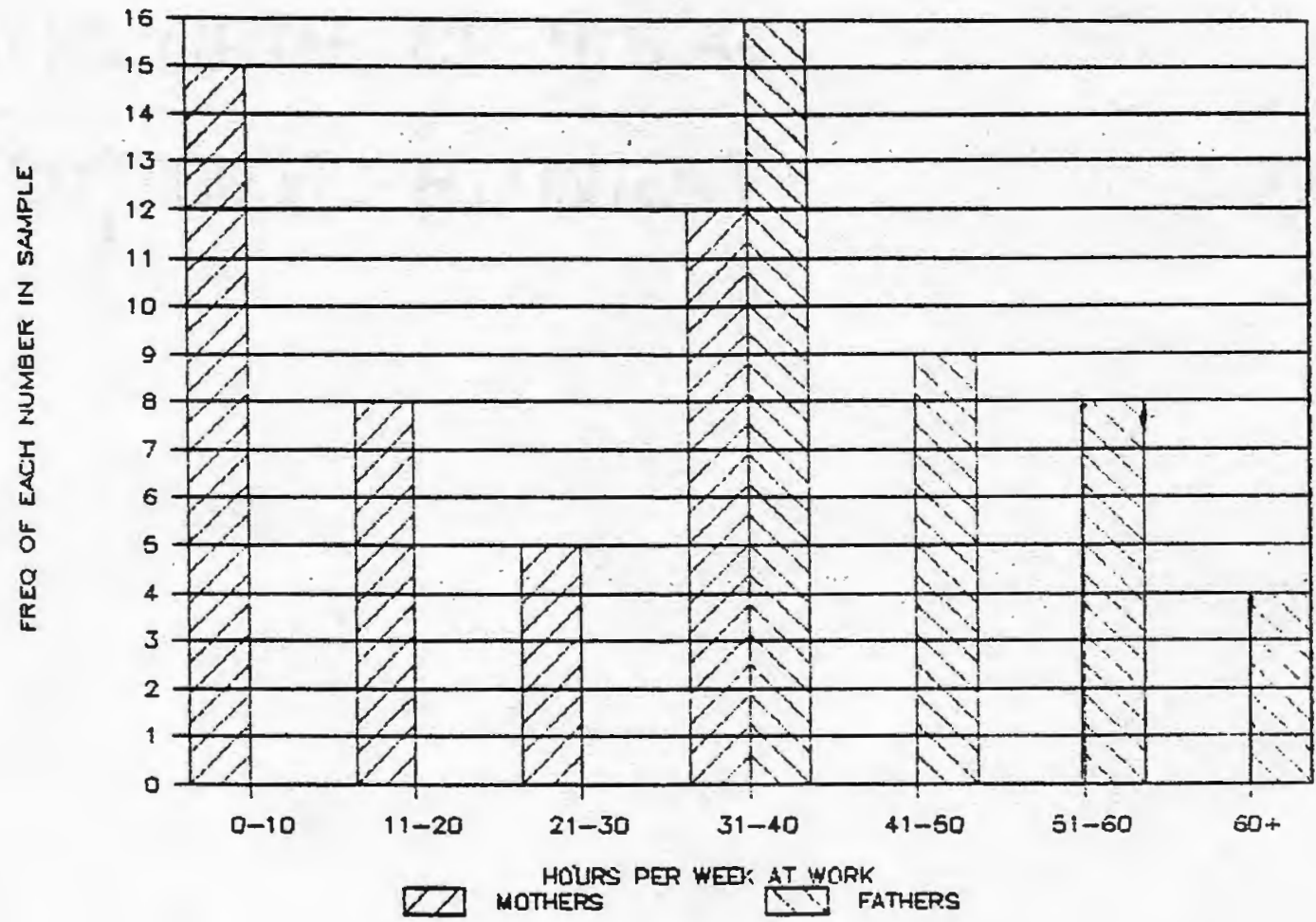

FAMILY INCOME

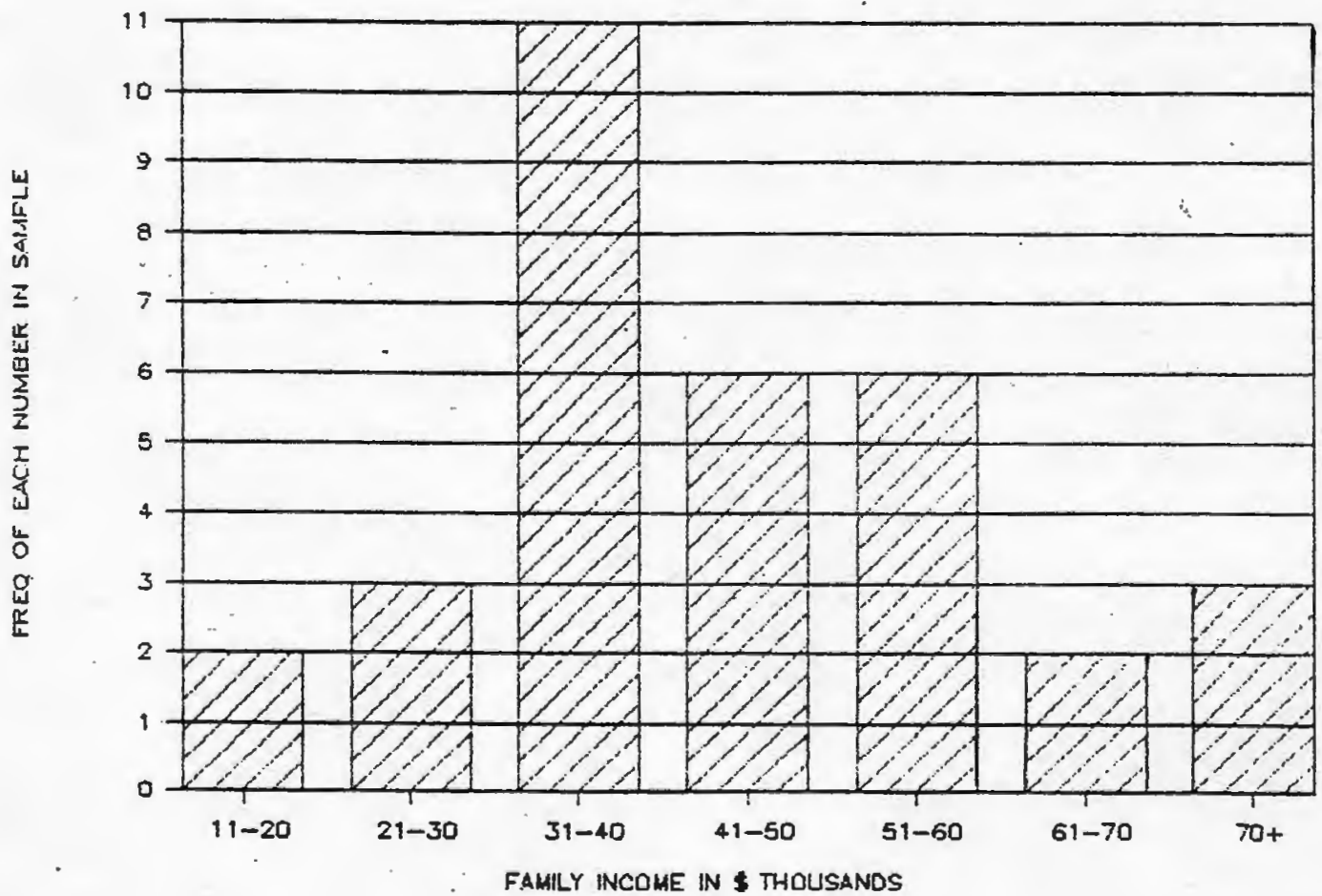


Danielle and Tommy were sitting together on the grass. Danielle was playing with her scampering kitty. Suddenly her kitty jumped on her lap and licked her on the nose. Tommy was watching the kitty and he thought it was silly that the kitty was licking Danielle on the nose. Danielle then felt the kitty scamper off her lap and watched it leap onto Tommy's lap. Tommy cuddled the kitty and felt the kitty's soft, fluffy fur. The kitty then left Tommy's lap and climbed into the tree in back of Tommy. Then Tommy looked at the tree, he could easily spot the kitty because of the pretty jeweled collar it was wearing around its neck. Danielle wished she had another kitty so that the two kitties could play together. She decided she would ask her mother if they could buy another kitty at the pet store. Tommy did not know what Danielle was thinking. Tommy then spotted the kitty on the branch above him. He reached up to get the kitty but the playful kitty jumped onto his shoulder instead. Tommy took the kitty off his shoulders and he felt its soft fur. Then Tommy's mother called for him to go home. He put the kitty in a kitty box. Later, when Tommy and Danielle went to the kitty box, the playful kitty looked up at them. They opened the box and Danielle felt the soft, fluffy kitty. She let the kitty down onto the grass and Danielle scampered and almost tripped over her playful kitty. 


\section{Fantasy-based story}

Danielle and Tommy were sitting together on the grass. Danielle was thinking about a flying kitty and suddenly-poof(!!!) right before her eyes a fluffy winged kitty floated down from the sky. Tommy could not see the winged kitty and he thought it was silly that Danielle said she was petting her soft winged kitty. Danielle then watched her kitty scamper out of her arms and leap onto Tommy's lap. Tommy could not see or feel the kitty. The kitty then left Tommy's lap, flapped its wings and flew into the tree in back of Tommy. As it did so, a jeweled collar appeared around its neck. Then Tommy looked at the tree; He could not see the kitty but he did see a jeweled collar hanging in mid air. Danielle wished for another kitty. She thought real hard and a fluffy cloud above turned into another flying scampering kitty. This time Tommy saw the kitty flying around overhead. Tommy felt the kitty land on his shoulder and Tommy picked it up and felt its soft fur. Then Tommy's mother called for him to go home. He put the kitty in a kitty box. Later, when Tommy and Danielle went to the kitty box, the kitty was not there-it had poofed(!!!) away. They opened the box - no kitty. Tommy could still see and touch the soft, fluffy kitty that he was thinking of. He picked up the kitty to feel its soft fur. Danielle also scampered with and tripped over the kitty that Tommy was thinking of . 
Appendix G

Categories of Explanations

(from Wellman and Estes 1986)

1. Mental term-repetition: Child uses the same mental term as that in the presentation (e.g., Why can't she touch it? "She's only pretending).

2. Mental term-substitution: Child uses a mental term not in the presentation (e.g., "It's just imagination").

3. Reality criteria: Child appeals to one of the three reality criteria.

a. Positive explanations mean the child asserts that the item meets the criteria (e.g., Why can she pet it? "Because she can touch it").

b. Negative explanations mean the child asserts that the item fails the criteria (e.g., "She CAN'T touch it": "It's invisible").

4. Reality status: Child refers to the reality of the item.

a. Positive explanations mean the child asserts that the item is real (e.g., "It's really a dog;" "It's a real one").

b. Negative use means the child asserts the item is not real (e.g., "It's a fake"; "It's not really a cookie").

5. Location or possession: Child refers to the location of the item or its possession by the character.

a. Positive explanations mean the child asserts that he item is there or is possessed (e.g. "It's there"; "His mother gave him one").

b. Negative explanations mean the child asserts that the item is not there or not possessed (e.g., "It's all gone"; "It's only in his mind").

6. Uninterpretable/I don't know: Child gives an uninterpretable explanation or says "I don't know," "Because," "He just does," etc. 


\section{Appendix $\mathrm{H}$ \\ CHILDREN'S VERBAL RESPONSES TO JUDGNENT IASK}

Codes:

* Interesting comment

** Experimenter 1 's subjects.

Experimenter 2's sub.jects are left unmarked.Appendix I

**1 R

Because it's inside of him - he's thinking. (F)

Cuz he's closing his eyes.

Because when he's thinking and he's trying to think of thinking of ants cuz both see ants before but not ants riding a bicycle.

Only if I have a picture of a pup inside me. (B)

I know a man who can turn into a car.

Cuz thinking is in his body. (C)

I dream about some.

Because it's inside of her. (E)

Because she has it. (A)

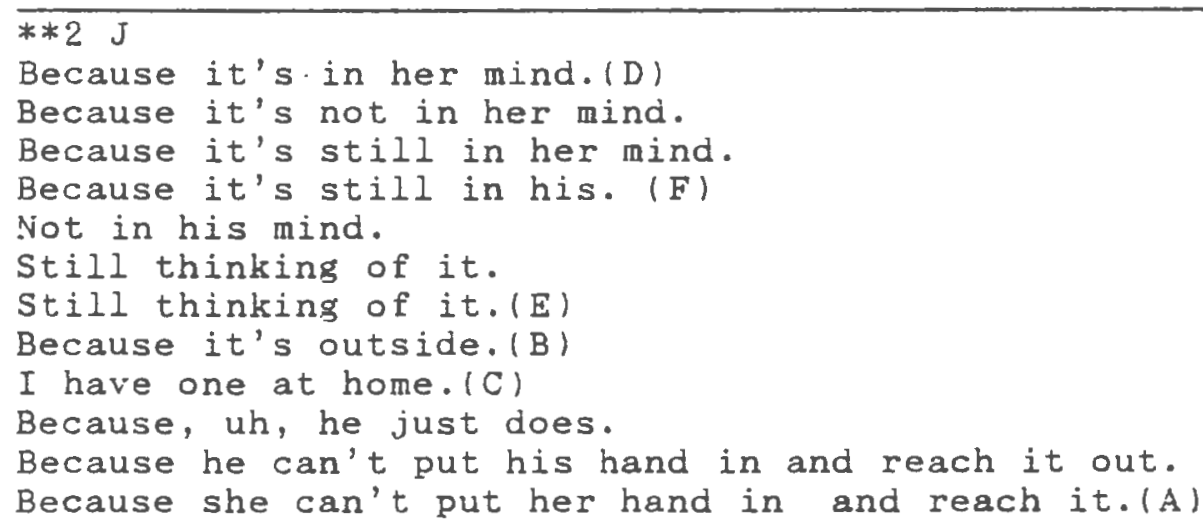


He's nice and soft. (B)

He flies away. (D)

Her eves are open.

It's good for you. (E)

She has to brush her teeth. (A)

It's not good for you.

*i $\mathrm{M}$

Don't know. (E, A, C, D, F)

He has it on a leash. (B)

$8 \mathrm{C}$

Don't know why. (B, $A, D, C, E, F)$

I his pinchurs to bite rou. (F)

$9 \mathrm{R}$

It's a cookie. (A)

The cookie will get rotten or eaten.

It's a puppy. (B)

It's a cupcake. (C)

It will fly away. (D)

It's a bird.

It will fly away.

It's an ant. (F)

Cause its an apple. (E)

It's not a real one.

**11 S - no responses (just noded)

**12 M

Cuz you can eat it. (E)

Cuz it just lay there.

*Cuz he can both share half of the cupcake. (C)

Cuz he can eat it at nighttime.

*Cuz if she touched it it would fly away. (D)

* Cuz she likes to see birds.

*Cuz I couldn't see it if I closed my eyes and think about it. $Q$

*Cuz I can't see it when I have my eyes closed.

**13 L

Because (D)

Because she's thinking about one. (E)

Because she's thinking about one but she can't see it because there is no kinda apple that can dance - that kinda would - She "s thinking of one but there's none.

Don't know. ( F, C )

**14C

Because he doesn't have. (C)

Because it's not there.

* No cuz it's not there, he's pretending he's holding it. (B)

(ans indicates that there is no puppy on pic or cookie card)

Because it's not there. $\{E\}$

But I saw an apple that I can eat. 
Because it would be there but you'd be thinking about it.

Cuz it might fall apart cuz ant's bones are really delicate. (F) Because it's not there

Because it might die.

That would be funny a little bicycle - there's no such thing.

Because it wouldn't be there but you could think about it.

Because it's not there. (D)

Because it might fly away up in the shy.

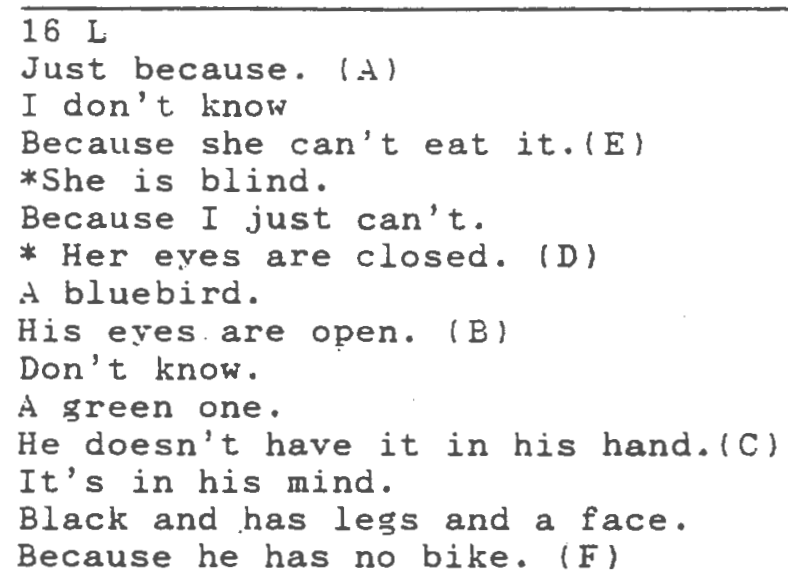


$19 \mathrm{~K}$

She has to eat it. (A)

That is how we think to sleep.

He has to pet it. (B)

It has to share the puppy to pet it.

If you want one.

He has to eat it. (C)

He has to take half.

He has to eat the whole thing.

It will bite. (D)

She has to be careful it will not bite.

It is small. (F)

Both have to see it.

It will walk all over and tickle.

She has to eat it. (E)

It will walk on her head.

It is step on us.

It doesn't dance, we eat it.

**21 E

Because he's thinking of it. (C)

Cuz it's invisible. (C, D, E, B)

Had one - nothing. (F)

**22 C

If he does it too hard it will squish him.(E)

Not if he's up in an airplane.

Only in a story.

Because if they're talking and look down and see puppies. (B)

If she wants to. (A)

If it was her pet. (D)

Not if she's thinking of one - cuz it's just her imagination.

She's just thinking of one.

Not if dancing - that would be a cartoon.(E)

That's silly.

Not if he's just thinking about one. (C)

Because of one - can't see if he's thinking of it.

**23 T

Because you can know what a cookie looks like. (A)

Because you know what a puppy looks like. (B)

Because you know what an ant on a bicrcle looks like. (F)

Because he doesn't have any? in his head. (C)

Because she's just thinking about it. (E)

Because it's not with her. (D)

Because thinking about it. 
**24 J

Because it's so grand, Giant people, giant monsters too, everyday. (E)

But $I$ can think about apples you can eat.

Because it's not so giant, it's small. (C)

Because he wants to eat a little piece. of it right now because he likes it.

I don't know how to think about it. I just know how to think about small apples.

All the time but ant's don't ride bicycles. (F)

Because he's going to have big bicrcle everyday.

Only seen ants but they walk.

I eat cookies. (A)

No, I don't want to.

Not when she closes her eyes. (D)

Because he has eyes open.

It might fly by everyday.

* Because I don't. want to. I want to think about apple you can eat.

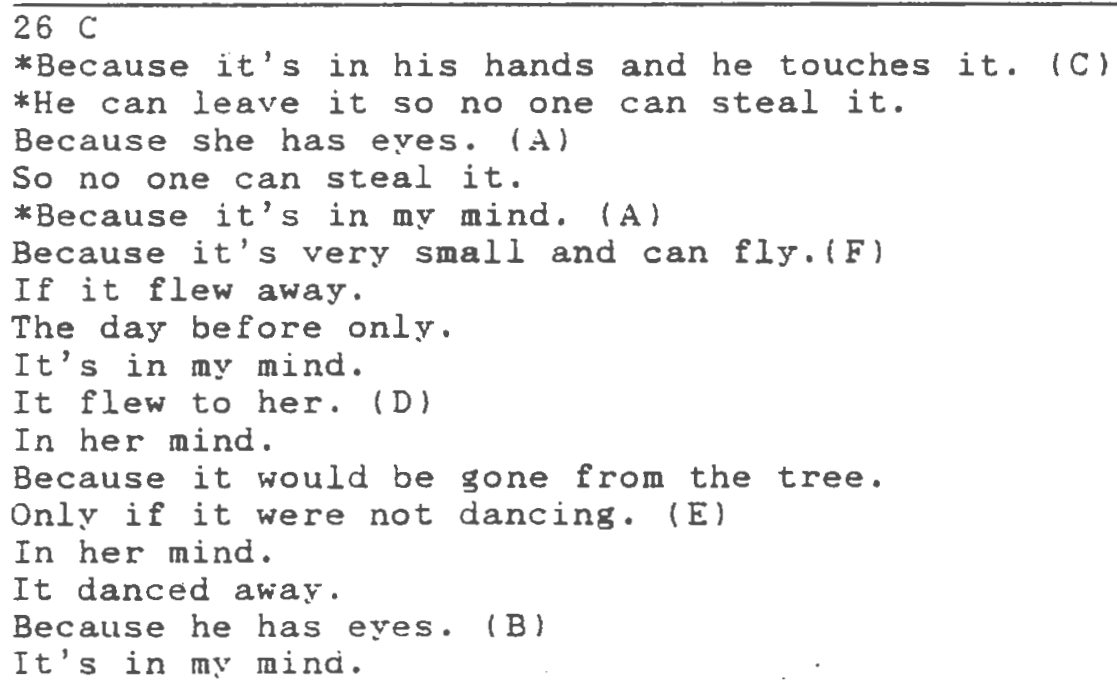


Her eres are opened. (E)

The apple will be there tomorrow.

**Apples can't dance.

$28 \mathrm{p}$

It's there all the time. (E)

Cause he doesn't think about it.

when I was a baby.

There is always one. (C)

He doesn't think about it.

It doesn't have a face on it.

It flies away. (D)

She doesn't think about it.

It won't fly away.

*There is always a bicycle. (F)

*It was in a store.

He bought one. (B)

$\mathrm{He}$ 's so soft and gentle.

There is always a cookie she makes. (A)

She likes cookies.

\section{$29 \mathrm{M}$}

Cause. (B, C, A, D)

Cause he has eyes. (F)

Cause he has hands.

Just an ant.

She has eyes. (E)

It's hers.

**31 A (shakes head - quiet)

Cuz she''s thinking of it. (D)

Cuz she can't see it.

Cuz he's thinking about it.(F)

Don't know.

**32 L

Not when she opens her eves. (D)

Cuz if it were in both minds they could see it.

Cuz she's just imagining it. (E)

Only if that friend is thinking about the appie that dances too.

only if he's thinking of it too. (F)

I don't know. (A)

My dad got 3 cupcakes from work.

Because he's just imagining it. (C)

**33 A

Because he's thinking of it and the other person can't see it.:C:

Because she's not the other person. (E)

Because that's what's in our dreams.

I usualiy get bad thoughts in my dreams so I get to go down with mo mother for cake and milk.

Her eyes are closed. (D)

I have one at home. 
Because not looking at it. (A)

Because it's not in her dream anymore.

Because it's a real puppy. (B)

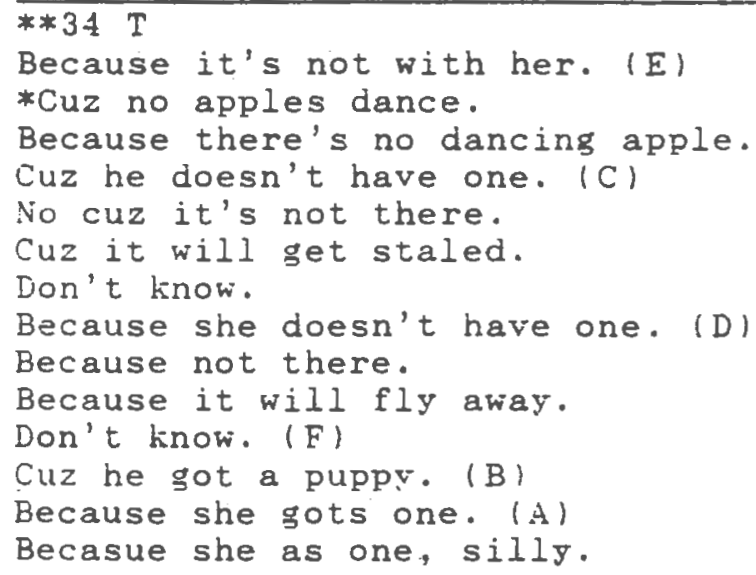


He has eyes. (B)

Cause it won't be broken.

It won't be broken. (D)

39 A

Cause he has eyes. (B)

Don't know.

He doesn't have it. (C)

He didn't have lunch yet.

She has it. (A)

She has eyes.

She didn't have lunch.

It flies but she can see it fly. (D)

They can look but not touch.

She can try to catch him.

It goes fist. (F)

People have eyes.

* I just saw an ant.

* People eat apples. (E)

I ate it.

$* \pm 1 \mathrm{~J}$

Because it's not there.(D,C, F,E)

It's silly.(F)

**42 R

Cuz. ( F)

**43 M

- Cuz. (E)

Not real.

Cuz he got eyes. (F)

No cuz might bite him. (D)

Cuz she got eyes.

Cuz come to her house.

Cuz he got eyes. (C)

After lunch.

**44 A

Because he doesn't have one. (C)

*Because it's just in the mind.

*Because it's just in her mind, she can't feel it. (E)

Cuz it's really in her mind, can't touch it or do ansthing wiz: anything.

Because if you wanted to you could.

Cuz it's in his mind. (F)

Cuz she has it in her hand. (A)

Because it's in his mind.

Cuz it's his puppy. (B)

Because it's in her mind. (D)

**Because no friends can see in other people's minds.

$45 \mathrm{C}$

Just because. $|F|$ 
Just can't.

No reason. (D)

Might not be there. (E)

*46 R

No reason. (C, E, A, B, D)

Cause he can see the road. (F)

$4 \mathrm{~T} \mathrm{P}$

There is no bird. (D)

Cause it is there.

Cause they are too tiny. (F)

It's very hard to see.

Then he'll see it.

It was climbing.

There is no make. (C)

Tomorrow it won' $t$.be there.

He knows it is there. (B)

He will see it.

She can't see one dancing. (E)

It's not there.

She will see it.

* Never saw one that dances.

She can't see it.(A)

She will see it.

Tomorrow she can eat it.

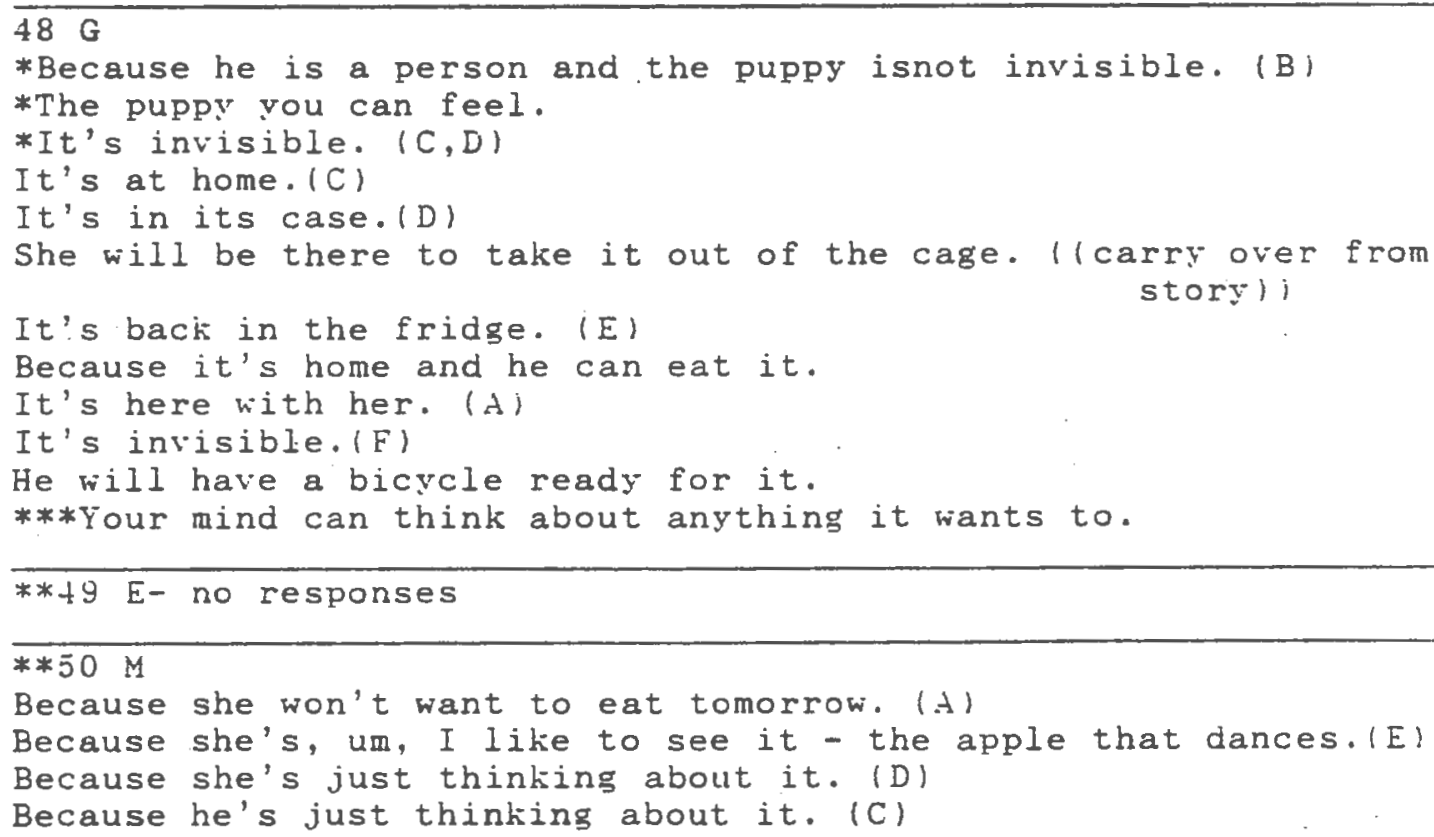


Because they have no feet.

*Because it's going to get all dirty and rotten. (A)

**52 L

If she wants to. (E)

Don't know. ( C, D, F, B)

$53 \mathrm{k}$

No reason. (B)

Just because. $(F)$

I don't know.

Just can't think of it.

Just can't do it. (E)

$54 \mathrm{C}$

No reason. (A)

Cause it's not there. (D)

It's not there. (C,E)

Cause it's there. $(E)$

Cause I can think about it.

It's not these. (F)

Cause it's there.

In my backyard.

Cause it's there. (B)

$55 \mathrm{~B}$

She sees with her eyes.(E)

It will still be there.

If it flies away she can't see it.(D)

Maybe it will still be there. (D)......( (diff focus))

Cause it's there. (A)

It comes back again.

Cause it was there. (C)

It could still be near him.

It will bite him. (F) It is still there.

It is soft.(B) It's on a leash.

$56 \mathrm{~L}$

Cause Alex is thinking of it. (F)

His eyes are open. (B)

It is still with him.

Because she is only thinking. (E)

Because Darlene is thinking of it -not her friend.

She is thinking of it. (D)

Because only Sara is thinking of it.

It is in her hand. (A)

She can put it in the cookie jar.

*He is only thinking of it. (C)

Only Jeff is thinking of it. 
Favorite Movies, Books, TV Shows

BOOKS

MOVIES

TELEVISION PROGRAYS

$1 \mathrm{R}$

Sesame books

Disney

Cartoon type

Sesame Street

Elephant Show

AM Sat. Cartoons

$2 \mathrm{~J}$

Dinosaur Days

Lost in Dinosaur World

Ghostbusters

Inspector Gadget

Cities of Gold

(Anything and Everyth)

The Little Prince

Julia Child

Wok with Yan

$3 \mathrm{M}$

Videos

He Man

Mr. Rogers

$4 \mathrm{~J}$ - no demographic info

$6 \mathrm{~T}$

Bambi

E.T.

Mickey \& the Giant

Micky Mouse

Walt Disner World

Lady and the Tramp

Snoopy

Sesame Street

Cars/Trucks

Ghostbusters/cartoon

Transformers

$7 \mathrm{M}$

Mercer Mayer Books

Ghostbusters

Big Bird

Dr. Seuss Books

Disney Books

Oliver \& Co.

Mickey Mouse Cartoon

Loves all types

Land Before Time

Bambi

Snow White

Full House

Perfect Strangers

Cartoons/ch.56

$8 \mathrm{C}$

Curious George

E.T.

Lady \& the Tramp

Alf

Little Red Caboose

An American Tale

Short Circuit

Cosby Show

Dr. Seuss

winnie the Pooh

webster

Lassie

Inspector Gadget

$9 \mathrm{R}$

Curious George

Pinocchio

Sesame Street

What did the Mailman brg Swiss Family Robnsn Mr. Rogers

Babar

This Old House

All my books:

wheel of Fortune

Heavy construction

$11 \mathrm{~S}-$ no demographic info 
$12 \mathrm{Y}$

Beatrix Potter Mother Goose Cinderella Sleeping .Beauty Bambi
Care Bears

Snow White

Cinderella

Sleeping Beauty
Sesame Street

Muppet Babies

Winnie the Pooh

Care Bears

Bugs Bunny

$13 \mathrm{~L}$

Richard Scary

Learning to Read

Kidsongs Circus

Sésame Street

$14 \mathrm{C}$

$A B C$

wizard of $\mathrm{Oz}$

Punky Brewster

Giving Tree

Cinderella

Scooby-do

Tiggy Goes to Hospital

Chipmunk Adventure

16 L - no demographic info

$1 T \mathrm{D}$

Sun's up

Duck's Birthday

The Giving Tree
Wizard of $\mathrm{Oz}$

Three Amigos

Dumbo
Alf

Cosby

winnie Pooh cartoon

$18 \mathrm{~N}$

Rose Petal Place

Oliver \& Co.

Sesame Street

The wuzzles Best Gift

Lady \& the Tramp

Wizard of $\mathrm{Oz}$

Today's Special

Cinderella

Snow white/7

Square One

Night Before Xmas

Cinderella

Dwarfs Zoobilie Zoo

Ch. 4

$19 \mathrm{~K}$

Cinderella

Cinderella

Sesame Street

Snow white

E.T.

Mr.Rogers-these onls

$21 E$ - no demographic info

$22 \mathrm{C}$

Mercer Meyer Books

Sesame Street Books

Animal books - all kinds
Barbar

Micks Mouse
Animal Programs

Morning Cartoons

$23 \mathrm{~T}$ - omitted this

$2+\mathrm{J}$

The Hobit

Curious George
Short Circuit

E.T.

The Hobit
Double Dare

Cartoons/Ghostbuster Jetsons.

Alf

21 Jump Street

Curious George

$26 \mathrm{C}$ - omitted this 
$27 \mathrm{~B}$

Tractor Book

Gold Bug Book
Superman

E.T.
Sesame Street

Nickelodian

Lassie

Dennis the Menace

\begin{tabular}{|c|c|c|}
\hline $\begin{array}{l}28 \text { P } \\
\text { Very Hungry Caterpillar } \\
\text { Inside Out } \\
\text { Happy Easter Book } \\
\text { Where Wild Things Are } \\
\text { Berenstain Bear Books }\end{array}$ & $\begin{array}{l}\text { E.T. } \\
\text { Oliver \& Co. } \\
\text { Lady \& the Tramp } \\
\text { Wizard of Oz } \\
\text { Ghostbusters }\end{array}$ & $\begin{array}{l}\text { Sat Cartoons: Suprman } \\
\text { Muppet Babies } \\
\text { Scooby Doo } \\
\text { Real Ghostbustr } \\
\text { Full House }\end{array}$ \\
\hline $\begin{array}{l}29 \text { M } \\
3 \text { Billy Goats Gruff } \\
\text { Curious Goerge Stories } \\
\text { Corduroy } \\
\text { Ernie Gets Lost } \\
\text { Dopey Dinosaur }\end{array}$ & $\begin{array}{l}\text { Roy Rogers Video } \\
\text { Superman } \\
\text { Land Before Time } \\
\text { American Tale } \\
\text { The } 3 \text { Amigos }\end{array}$ & $\begin{array}{l}\text { Brave Start } \\
\text { Gene Autry westerns } \\
\text { Roy Rogers } \\
\text { Sharon.Lois \& Brahm } \\
\quad \text { (Elephant Show) } \\
\text { The Little Koala } \\
\text { Maple Town }\end{array}$ \\
\hline
\end{tabular}

$31 \mathrm{~A}$

Thingamajig

snow white

Cinderella
Disney

Bill Cosby

Cartoons

\section{$32 \mathrm{~L}$}

Peter Pan

Care Bears

Sweet Dreams for Sally

A Friend for Francis winnie the Pooh

\section{Bambi}

Cindereella

Pinocchio

Alice in wonderld

Care Bears-wonderld
My Little Pony

Muppet Babies

Hello Kitty

Furrytale Theatre

$34 \mathrm{~T}$

Wizard of $\mathrm{Oz}$ Jem

Care Bear/Nutcrackr Punky Brewster

\section{$36 \mathrm{~A}$}

Red Caboose

We Help Mommy

$37 \mathrm{~A}$

Brown Bear

Goodnight Book
Mary Poppins

Charlotte's web

Land Before Iime

All Walt Disney

E.T.

My Little Pony

American Tail

wizard of $\mathrm{Oz}$
Mr. Rogers

Sesame St.

38 S
Disney Books
Bedtime Stories
Animal Books

$38 \mathrm{~S}$

Animal Books
Punky Brewster Different Strokes Sesame Street 
39 A

Curious George Series

Katy No Pocket

Lion, witch, wardrobe Sesame Street

She-Ra

Pinwheel

Angelina Ballerina

Muppets Movie

Heathcliff

Annie \& the Fild Animals Cinderella

She-Ra

Very Hungry Caterpillar

Mary Poppins

Count Dracula

$42 R$

Goldilocks/3bears

Beverly Hills Cop

Alf

Amelia Bedelia Stories

Ghostbusters

Sesame Street

Wrestling

Sesame St. Books

Mr. Rogers

Dr. Seuss Books

Today's Special

43 it

Curious George

Disney

Sesame Street

Little Train that Could

Dinosaurs

Alf

Scuffy the Tugboat

Cartoons

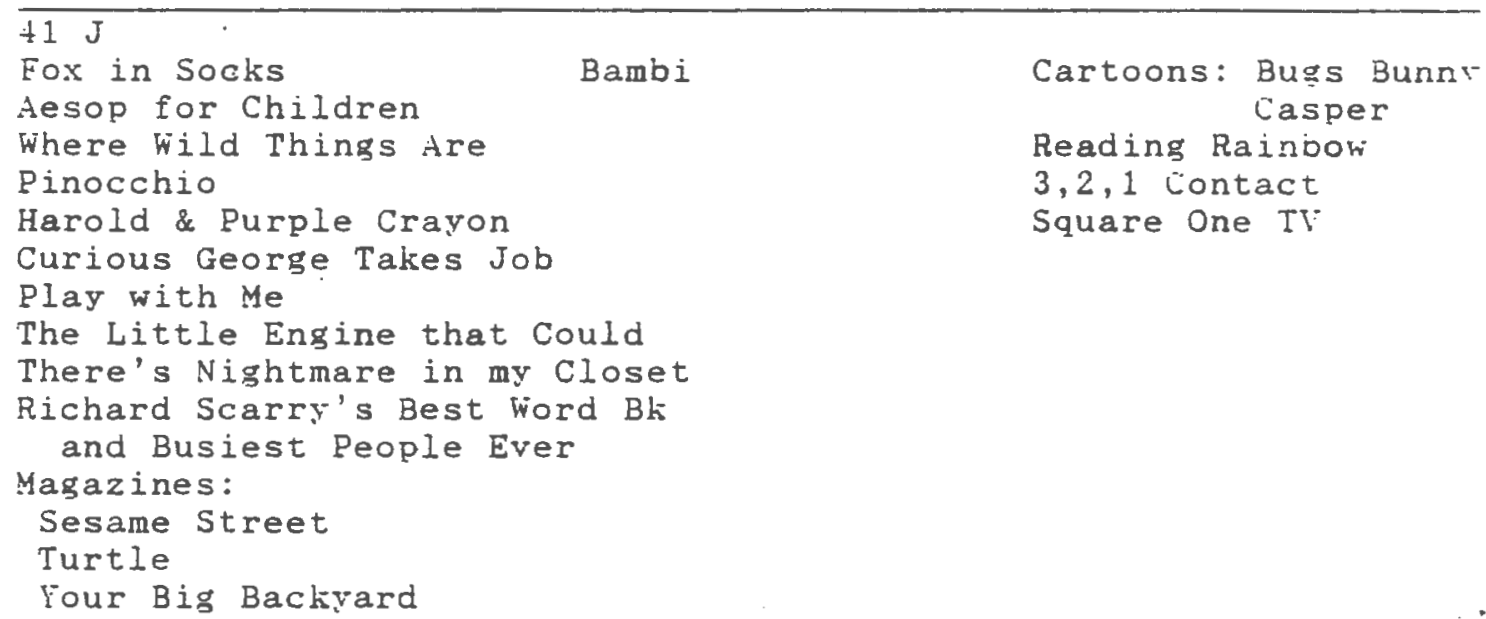

Cartoons: Bugs Bunnr Casper

Reading Rainiow

$3,2,1$ contact Square One TY

Ghostbusters

Land Before. Time 
$47 \mathrm{P}$

Inspector Gadget

Great Mouse Detective

Trucks
Oliver \& Co.

Top Gun

Dumbo
Square One 3-2-1 Contact Reading Rainbow Sesame Street

48 G

Go Dog Go

Titanic

Nature \&Other Earthlings

Berenstain Bears/Spooky

old Tree
E.T.

Chitty Chitty Bang

Love Bug

Pete's Dragon

Pooh
Charlie Brown Speci

Duck Takes

Disney

Gummi Bears

Sesame Stree L

Mr. Rogers
$49 \mathrm{E}$

All books
Pippi Longstocking
Sesame Street

Kidsongs

$\mathrm{Mr}$. Rogers

$50 \quad y$ - omitted this part

$51 \mathrm{~K}$

Dr. Seuss Books

Sesame Street Books
Space Camp

Lady and the Iramp

Care Bears

Cinderella
Sesame Street

Mr. Rogers

Full House

52

Emily -omitted this info

$53 \mathrm{~K}$ - no demographic info

$54 \mathrm{C}$

Berenstain Bears Series lione in particular

Sesame Street

Dr. Seuss books

Mike Mulligan\&Steam Shovl

Corduroy

Richard Scarry Stories

Mr. Rogers

Square One TV

321 Contact

Going Places etc

\section{$\overline{5 j} B$}

Cat in the Hat

Curious George

Robert the Horse

Winnie the Pooh

The Little Red Hen

$5 T \mathrm{~L}$

almost any kind
E.T.

Sleeping Beauty

Hary Poppins

Annie
Sesame Street

$\mathrm{Mr}$. Rogers

Zoobilee Zoo

Maple Town
Vialt Disney Movies

Land Before Time

Pippi Longstockings
Todar's Special

Elephant Show

Punky Brewster 


\section{BIBLIOGRAPHY}

Barnes, H. \& Lyons, N. (1986). Education as an art: The Rudolf steiner method. Massachusetts: Association of Waldorf Schools.

Berzonsky, M. (1971). The role of familiarity in children's explanations of physical causality. $\underline{\text { Child }}$ Development, $42,705-715$.

Brainerd, C.J. (1978). Piaget's theory of intelligence. New Jersey: Prentice-Hall.

Bringuier, J. (1980). Conversations with Jean Piaget. Chicago: University of Chicago Press.

CampbeII, S. (Ed.). (1980). Piaget Sampler: An introduction to Jean Piaget through his own words. New York: John Wiley \& Sons.

Collyer, C. E. \& Enns, J. T. (1987). Analysis of Variance: The basic designs. Chicago: Nelson-Hall.

Dworetzsky, J. (1984). Introduction to child development. New York: West Publishing Co.

Estes, D., Wellman, H., \& J. Woolley. (in press). Child's understanding of mental phenomena. Manuscript submitted for publication. To appear in $\mathrm{H}$ Reese (Ed.), Advances in child development and behavior, vol. 21 .

Inhelder, B. \& Piaget, J. (1958). The growth of logical thinking: From childhood to adolescence. New York: Basic Books.

Inhelder, B., Sinclair, H. \& Bovet M. (1974). Learning and the development of cognition. Massachusetts: Harvard University Press.

Kelley, D. (1984). A theory of abstraction. Cognition and brain theory, VII $(3 \& 4)$, summer/fall.

Kelley, D. (Speaker). (1986). The nature of freewill (cassette recording) Toronto: The Portland Institute.

Kelley, D. (1986). The evidence of the senses. Baton Rouge, Louisiana: Louisiana State University Press.

Keppel, G. (1982). Design and analysis (2nd ed). New Jersey: Prentice-Hall. 
Koutsourais, H. (1984). Inhibiting magical thought through stories. Child Study Journal 14, 227-236.

Lesser, R. \& Paisner, M. (1985). Magical thinking in formal operational adults. Human Development 28, 57-70.

Modgil, S. \& Modgil, C. (1976). Piagetian research: Compilation and commentary (Vols. 1-8). Great Britain: NFER Publishing.

Montessori, M. (1965). Dr. Montessori's own handbook. New York: Schocken Books.

Morison, P. \& Gardner H. (1978). Dragons and dinosaurs: The child's capacity to differentiate fantasy from reality. Child Development, 49. 642-648.

Philitps, D. (1982). Perspectives on Piaget as Philosopher: The tough, tender-minded syndrome. In Modgil, S. \& Modgil, C. (Eds.) Jean Piaget: Consensus and controversy. (pp. 13-29). Praeger Special Studies, Praeger Scientific.

Phillips, J. (1975). The origins of intellect: Piaget's theory. San Francisco: W.H. Freeman \& Co.

Piaget, J. (1929). The child's conception of the world. London: Routledge and Kegan Paul Ltd.

Piaget, J. (1951). The child's conception of physical causality. London: Routledge \& Kegan Paul Ltd.

Piaget, J. (1952). Judgment and reasoning in the child. New York: Humanities Press.

Piaget, J. (1962). Play, dreams and imitation in childhood. New York: Norton \& Co.

Piaget, J. (1972). The principles of genetic epistemology. New York: Basic Books.

Piaget, J. (1971). Psychology and Epistemology. (A. Rosin, Trans). New York: Grossman Publishers. (Original work published in 1970).

Piaget, J. (1972). The principles of genetic epistemology. (W. Mays, Trans.). New York: Basic Books. (Original work published 1970).

Peikoff, L. unpublished lectures given during sundry conferences. 
Prentice, N., Manosevitz, M., \& Hubbs, L. (1978). Imaginary figures of early childhood: Santa Claus, Easter Bunny, and the Tooth Fairy. American Journal of orthopsychiatry, $48(4), 618-628$.

Rand, A. (1968/1975). The new left: The anti-industrial revolution. New York: New American Library.

Rand, A. (1979). Introduction to objectivist episetemology. New York: New American Library.

Randall, T. \& Desrosiers, M. (1980). Measurement of supernatural belief: Sex differences and locus of control. Journal of Personality Assessment, 44(5), 493-498.

Shatz, M. Wellman, H.M., \& Silber, S. (1983). The acquisition of mental verbs: A systematic investigation of the first reference to mental state. Cognition, 14 , 301-321.

Sigel, I. (1985). Parental belief systems: the psychological consequences for children. New Jersey: Lawrence Erlbaum Associates.

Wellman, H. (1985). The origins of metacognition. In D. Forrest-Pressley, G. MacKinnon, \& T. Waller (Eds) Metacognition, cognition, and human performance (pp. 1-31). San Diego: Academic Press.

Wellman, H. \& Estes, D. (1986). Early understanding of mental entities: A re-examination of childhood realism. Child Development, 57, 910-923. 